(II) Nordic Council of Ministers

HIGHER EDUCATION, RESEARCH AND INNOVATION

A feasibility study on how to strengthen Nordic-American cooperation
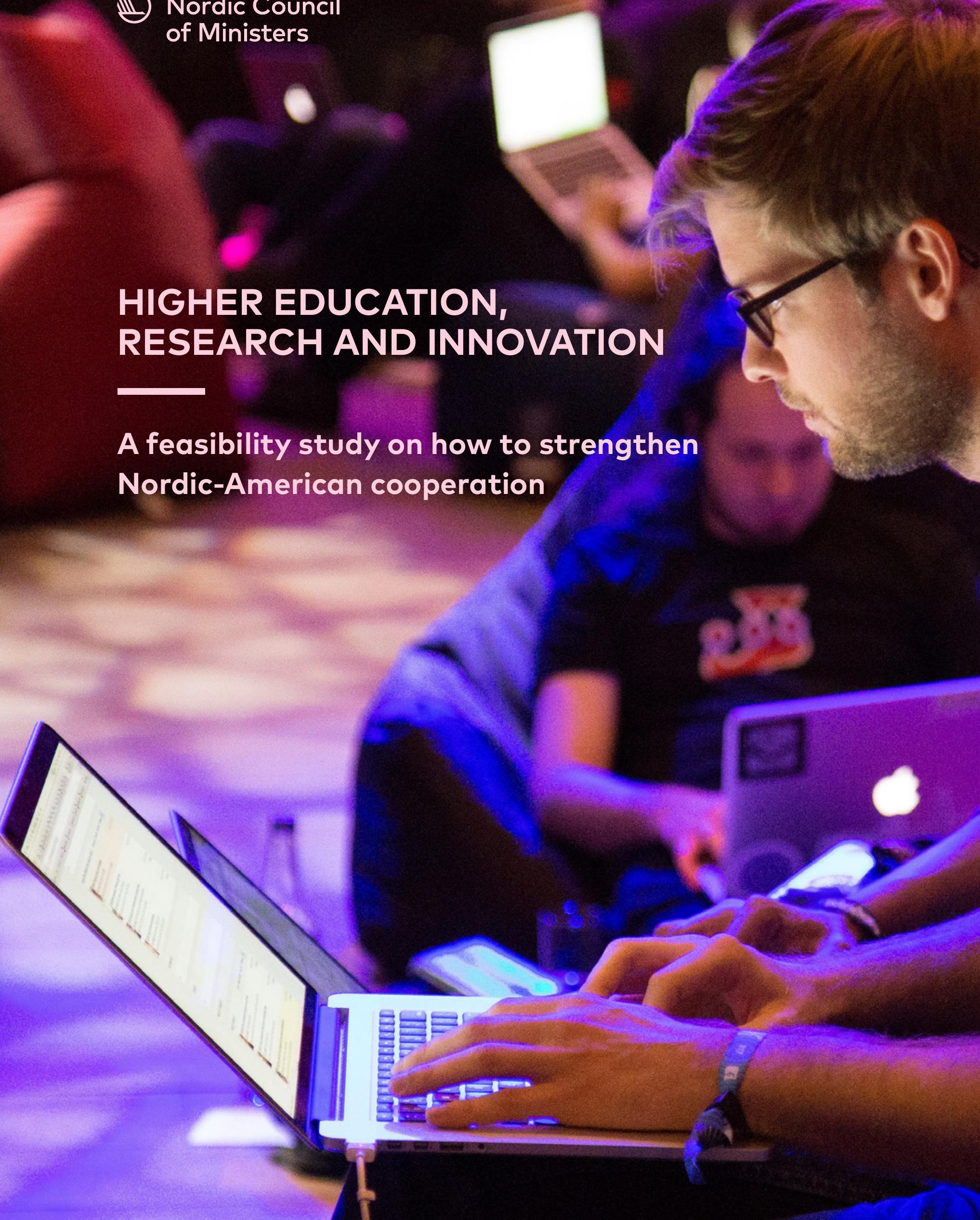



\section{Higher education, Research and Innovation}

A feasibility study on how to strengthen Nordic-American cooperation

Oxford Research A/S

TemaNord 2018:502 
Higher education, Research and Innovation

A feasibility study on how to strengthen Nordic-American cooperation

Oxford Research A/S

ISBN 978-92-893-5346-5 (PRINT)

ISBN 978-92-893-5347-2 (PDF)

ISBN 978-92-893-5348-9 (EPUB)

http://dx.doi.org/10.6027/TN2018-502

TemaNord 2018:502

ISSN ogo8-6692

Standard: PDF/UA-1

ISO 14289-1

(c) Nordic Council of Ministers 2018

Cover photo: unsplash.com

Print: Rosendahls

Printed in Denmark

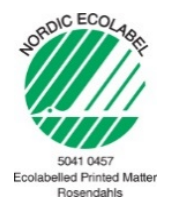

Disclaimer

This publication was funded by the Nordic Council of Ministers. However, the content does not necessarily reflect the Nordic Council of Ministers' views, opinions, attitudes or recommendations.

Rights and permissions

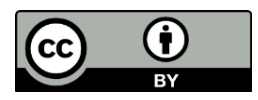

This work is made available under the Creative Commons Attribution 4.0 International license (CC BY 4.0) https://creativecommons.org/licenses/by/4.0

Translations: If you translate this work, please include the following disclaimer: This translation was not produced by the Nordic Council of Ministers and should not be construed as official. The Nordic Council of Ministers cannot be held responsible for the translation or any errors in it.

Adaptations: If you adapt this work, please include the following disclaimer along with the attribution: This is an adaptation of an original work by the Nordic Council of Ministers. Responsibility for the views and opinions expressed in the adaptation rests solely with its author(s). The views and opinions in this adaptation have not been approved by the Nordic Council of Ministers. 
Third-party content: The Nordic Council of Ministers does not necessarily own every single part of this work. The Nordic Council of Ministers cannot, therefore, guarantee that the reuse of third-party content does not infringe the copyright of the third party. If you wish to reuse any third-party content, you bear the risks associated with any such rights violations. You are responsible for determining whether there is a need to obtain permission for the use of third-party content, and if so, for obtaining the relevant permission from the copyright holder. Examples of third-party content may include, but are not limited to, tables, figures or images.

Photo rights (further permission required for reuse):

Any queries regarding rights and licences should be addressed to:

Nordic Council of Ministers/Publication Unit

Ved Stranden 18

DK-1061 Copenhagen K

Denmark

Phone +4533960200

pub@norden.org

\section{Nordic co-operation}

Nordic co-operation is one of the world's most extensive forms of regional collaboration, involving Denmark, Finland, Iceland, Norway, Sweden, and the Faroe Islands, Greenland and Åland.

Nordic co-operation has firm traditions in politics, economics and culture and plays an important role in European and international forums. The Nordic community strives for a strong Nordic Region in a strong Europe.

Nordic co-operation promotes regional interests and values in a global world. The values shared by the Nordic countries help make the region one of the most innovative and competitive in the world.

The Nordic Council of Ministers

Nordens Hus

Ved Stranden 18

DK-1061 Copenhagen K, Denmark

Tel.: +4533960200 www.norden.org

Download Nordic publications at www.norden.org/nordpub 



\section{Contents}

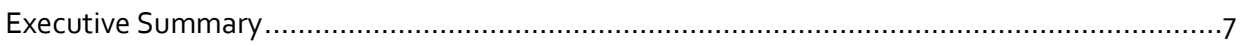

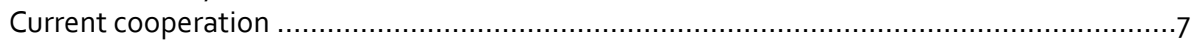

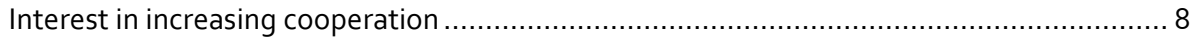

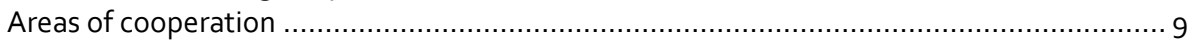

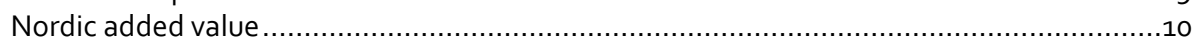

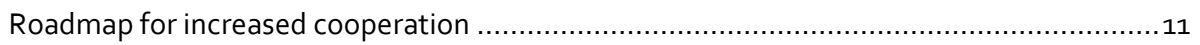

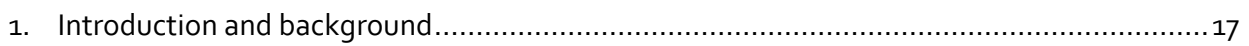

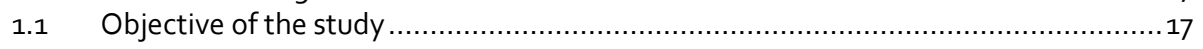

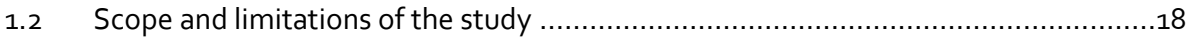

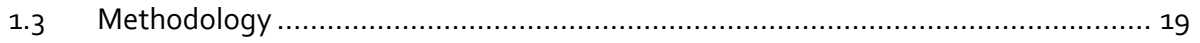

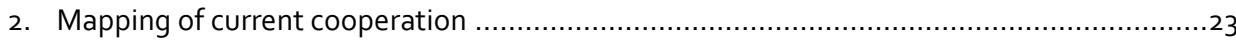

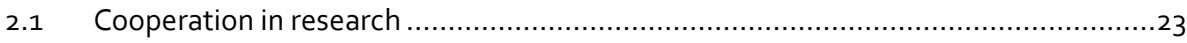

2.2 Agreements between the US and the Nordic countries within research, higher education and innovation ..................................................................... 26

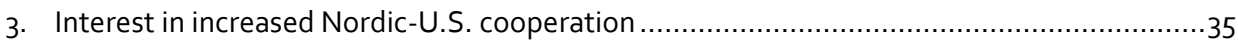

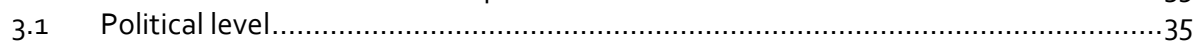

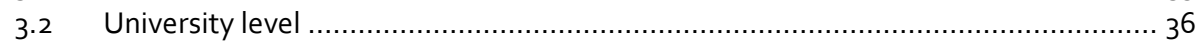

3.3 Focus areas of further cooperation within research and innovation ......................38

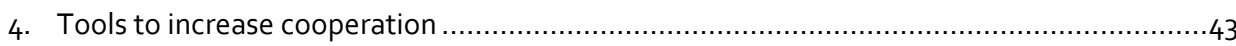

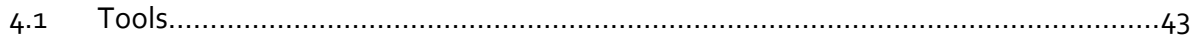

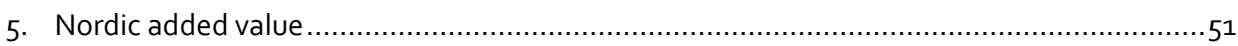

5.1 The Nordic added value of enhanced cooperation with the U.S. within higher education, research and innovation ........................................................ 51

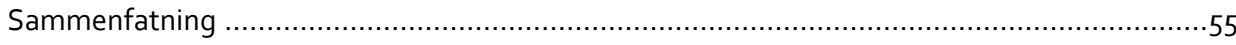

Appendix A: Nordic country report on cooperation agreements with the U.S..................57

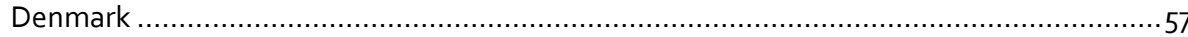

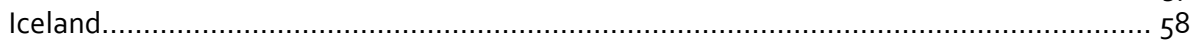

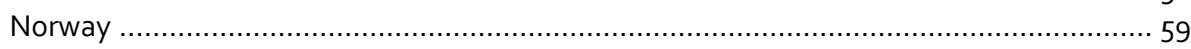

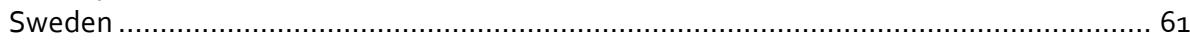

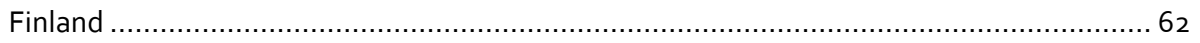

Appendix B: Exchange of students between the U.S. and the Nordic Countries ..................... 65

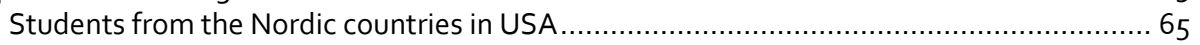

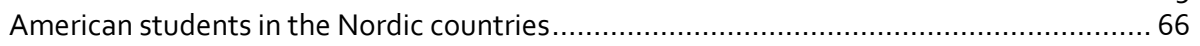

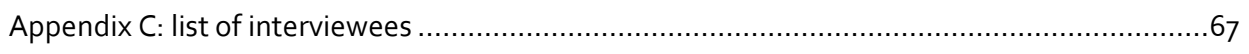

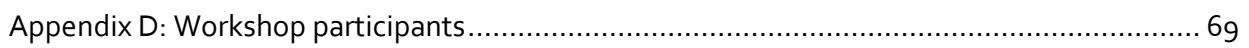





\section{Executive Summary}

This feasibility study examines the potential for increased cooperation within higher education, research and innovation between the U.S. and the Nordic countries Denmark, Sweden, Norway, Finland and Iceland. The study shows that cooperation is already well established and that Nordic universities already cooperate frequently with American universities. At the same time, there is an interest in and potential for even stronger collaboration.

\section{Current cooperation}

In connection to this study Science Metrix has carried out a bibliometric study of the cooperation in research between the Nordic countries and the U.S. over the period 2006-2015. The bibliometric study uses co-authorship of scholarly articles as a definition of collaboration, capturing one important - but not all - facets of research partnerships. The study shows that the Nordic countries publish about $50 \%-55 \%$ of their papers in international collaboration, and about $15 \%$ of their papers with a U.S. co-author specifically. This equals about 100,000 Nordic-U.S. collaborations over the study period. While this is a high number it is only about $65 \%$ of what would be expected - about 147,000 papers - given how much the countries participate in international collaborations generally, and the size and collaboration of the global research community more broadly.

The expected collaboration rate does not take into account such things as geographical distances, cultural differences and existence research infrastructure, such as funding of joint research. Given the geographical distance and the fact that the U.S. is for example not part of Horizon 2020 - and previously FP6 and FP7 - it is not surprising that collaboration is lower than what would have been expected from the countries' participation in international cooperation generally. Countries such as the UK, Germany and Netherlands also have lower collaboration rates with the U.S. than expected and the Nordic countries collaborate with each other 3-4.5 times as often as expected, demonstrating their strong geographical, historical and cultural ties.

At the same time - in an increasingly global world, where research, education and innovation is becoming more and more international and where geographical distances play a smaller and smaller role - it indicates that there is room for even stronger collaboration within higher education, research and innovation.

The desk research, followed by interviews show that each Nordic country have established national agreements on a bilateral level with the U.S., however the agreements mainly facilitate further collaboration within research. While there are many agreements between the U.S. and the Nordic countries on the university level, 
the study show that the cooperation within research and exchange of researchers are largely based on personal relations.

Agreements at the university level is, however, an often used tool to promote exchange of students and all the Nordic Universities have student exchange agreements with American Universities and many have agreements with a large number of American universities. On some of the agreements the activity is low, which is mainly because the agreements are 1:1 exchange agreements, which suffer from a lack of interest from American students to study in the Nordics. Also, most American students seek exchange as part of their bachelor degree, where the supply of courses in English are often more limited at the Nordic universities compared to master level.

Innovation cooperation is often focused on Silicon Valley and anchored at the relevant institutions in Silicon Valley, primarily the Nordic Innovation House and Innovation Center Denmark. Cooperation has been growing in recent years with several new initiatives being launched.

\section{Interest in increasing cooperation}

The quantitative bibliometric findings are well aligned with the qualitative findings of this feasibility study, namely that cooperation is well established but that there is an interest in collaborating even more intensely. The Nordic universities see the American universities as interesting partners due to the resources they have available and the high quality of their research. And both students and researchers generally find the U.S. to be an interesting country to study or do research in. Also, the cultural barriers are seen as small since students and researcher from the Nordics have good language skills and a similar tradition for independent research and education as Americans. Thus, cooperation between Nordic and U.S. researchers is characterised as relatively smooth and Nordic students generally settle well in the U.S. and at U.S. universities.

Similarly, the Nordic stakeholders in the U.S. experience the interest from American universities in the Nordics as high and Nordic research and education is regarded as being of very high quality. In addition, there is a growing interest in "the Nordic way of life" and the societal model combining strong, competitive economies with a focus on work-life balance, sustainability and quality of life.

Innovation cooperation is mainly facilitated by the Nordics seeking inspiration from the US. American focus on increasing its innovation capacity through cooperation with the Nordics are limited. However, an interest in learning more about the Nordic model, Nordic way of life and how the Nordic companies combine corporate social responsibility and work-life balance with growth and profitability is increasing and could well be an area to explore and support further in the future.

Despite the positive attitude towards increasing cooperation a few interviewees have also questioned why efforts to increase internationalisation of research, higher education and innovation should focus on the U.S. in particular? Especially at a time where most funding is dedicated to subject areas as opposed to countries and where all 
the Nordic countries are investing large resources in European collaboration, mainly through Horizon 2020.

However, the majority of representatives from both national research councils, private funds sponsoring research and universities do regard the U.S. as a country of particular interest due to the resources available and competencies at American universities. The high frequency of world class universities in the U.S. justifies for many a particular focus on the U.S. in addition to the focus on national, Nordic and European research and education collaboration.

\section{Areas of cooperation}

The Nordic-American collaboration spans a wide variety of areas but with collaboration being more intense in some areas than others. Looking at co-authorships Nordic-U.S. collaboration is by far the most frequent in health \& medicine (app. 150,000 copublications from 2006-2015) followed by biotechnology (app. 85,000) and ICT (app. 35,000 ). This is not surprising since these are also by far the areas, which has the largest publication output. Food, energy production, fisheries and space follow next with about 20,000-14,000 co-publications. These are all areas with a medium publication output.

If we instead look at where collaboration is most frequent taking the size of the research areas into account space research and arctic research are the areas of most frequent cooperation between the Nordics and the U.S., with the U.S. co-publishing with the Nordics in about $4 \%$ and $10 \%$ of its publications. ${ }^{1}$ Biotechnology and health \& medicine are areas of mid-range collaboration frequency for the Nordic-U.S. partnership ( $2.7 \%$ and $2.1 \%$ collaboration rate), while the remaining six areas assessed in the bibliometric study are below the average for Nordic-U.S. collaboration across areas (fisheries \& agriculture, food research, energy production, ICT, environmentally friendly solutions and space and defence).

High collaboration frequency in a research area indicates that both the U.S. and the Nordics have strong interests and competences in the area. But based on the data alone it is not possible to say if there is also room for even stronger cooperation due to the shared interest and competences or if there is little room for stronger collaboration because collaboration is already well established and options exploited. Similarly, with the areas of infrequent collaboration. This could indicate little shared interest and/or limited competencies or a large potential for increased collaboration. Therefore, the interviews have also focus on discussing which areas have potential for increased collaboration.

The interviewees have in particular pointed to arctic research, health \& medicine as well as clean energy and environmental friendly solutions as areas which in particular have special potential for collaboration.

\footnotetext{
${ }^{1}$ It is important to keep in mind that there is a much smaller international community involved in arctic research, and so the
} Nordic countries and the United States have a smaller pool of potential partners abroad from which to choose. 
As mentioned Arctic research is already one of the areas with the most frequent collaboration but at the same time a very small area. Collaboration within health and medicine is by far the largest area of publication output and collaboration is fairly frequent. Here the Nordic countries are not only an attractive partner due to its competencies but also due to the relatively small populations, possibilities to do clinical trials and the data registers, which make it possible to follow people and their health over time. For clean energy and environmentally friendly solutions frequency of collaboration is below average and for clean energy the bibliometric study shows that collaboration has been falling over time indicating there is room for improvement.

Interviewees and participants in the workshop have also pointed out that the focus areas of increased collaboration should be aligned with areas which each country have highlighted as important in their research and innovation strategies as well as the strategies pursued by the national research councils. If an area is not a priority for the majority of countries interviewees foresee that it can be difficult to gather support for increased cooperation. Similarly, the universities should be included in discussions of increased future collaboration to make sure the focus areas are aligned with their priorities and competences.

\section{Nordic added value}

A precondition for acting at the Nordic level is the existence of Nordic added value, i.e. that it adds value to act in collaboration compared to the countries acting on their own. Thus, the feasibility study has also assessed if it adds value for the Nordic countries to increase cooperation with the U.S. as one entity compared each country doing the same on their own.

Generally, there is support for approaching increased cooperation at the Nordic level in both the Nordic countries and the U.S. Some also highlight, however, that they are unsure of the Nordic added value and would like to see Nordic added value analysed in more detail.

Nordic added value has especially been highlighted in relation to:

- Attractiveness as a partner for the U.S. The Nordics are more attractive as a partner than the Nordic countries individually. This is especially an advantage when establishing collaboration with the most prestigious American universities, who receive many requests for collaboration;

- Critical mass. In relation to the above the Nordics have a larger pool of world class institutes and researchers within a given area than the countries individually, which increases the chances of forming partnerships between world leading researchers from the Nordics and the U.S.;

- Appropriate size. The Nordic countries, universities and research programmes are often small compared to the U.S. but the Nordics as one region with pooled resources is a more equal partner to American stakeholders; 
- Resource efficiency. It is more efficient to promote the Nordic countries as one entity and establishing joint cooperation agreements instead of each country promoting itself and establishing its own agreements. Some have also highlighted that the Nordic brand is stronger in the U.S. than the brand of any country individually.

\section{Roadmap for increased cooperation}

As described above the study provides support for the Nordic Council of Ministers to proceed with its efforts to increase cooperation between the Nordics and the U.S. in research, higher education and innovation. But how can this be done? Who should be involved? What areas should future collaboration focus on? Which tools should be used to increase cooperation? Based on the analysis we present our recommendations to these questions in the following roadmap. We have divided the recommendations for future action into political and organisational aspects on the one hand and operational aspects on the other.

\section{Political and organisational aspects}

Two key aspects going forward is to decide which actors to involve and what areas to focus on.

\section{Which actors to involve?}

While the relevant actors to involve depends on what exactly the Nordic Council of Ministers decide to do and how they do it some general guidelines can be developed for who to involve.

The Nordic Council of Ministers is an intergovernmental body and decisions are made by the representatives from the Nordic Governments. The responsibility for the current feasibility study and the work on increased cooperation with the U.S. within higher education, research and innovation is under the Committee for Education and Research and it will be the Committee, which decides on future actions based on the feasibility study. The relevant authorities responsible for education and research in each country are therefore key to involve to make sure the work has the necessary political support. Due to the processes and decision-making structures in the Nordic Council of Ministers this should happen automatically.

The current study has also involved the relevant staff at the Nordic embassies in Washington and innovation centres in Silicon Valley in the study as they followed the agenda for education, research and innovation closely, have contacts to many relevant American stakeholders and have experience with establishing cooperation agreements with American organisations. They are therefore relevant to involve to make sure that ideas for future work is aligned with American priorities and to help establish contacts with the relevant American authorities and organisations. 
Existing Nordic actors within higher education, research and innovation are also key to involve in future work. Since the Nordic countries have already tasked them with facilitation cooperation within higher education, research and innovation it is much easier to build on them instead of having to agree on new structures from scratch. NordForsk, Nordic Innovation, Nordplus and the Nordic Innovation Houses in Silicon Valley and New York are of particular relevance to include.

The national research councils have also been pointed out as a key actor to involve since they fund a substantial amount of research in each country and are important players in developing strategies and priorities for research, funding options and concrete calls. The research councils are especially relevant if the Nordic Council would like to define focus areas and if they would like to set up concrete funding mechanisms for U.S.-Nordic cooperation.

The Nordic countries also have significant private foundations, which sponsor both public and private research. A few have been interviewed for this study and they have also showed an interest in increased cooperation with the U.S. Whereas the budgets of several of the national research councils' have been cut lately some of the private foundations have increased their budgets for funding of research.

The universities are also key players for increased cooperation and are key to involve to make sure that they find future actions and initiatives relevant. The universities can also help point to areas of special interest or potential. One or two universities from each country could be involved in future work to increase cooperation. This could for example be the universities which have the most co-publications with American researchers as identified by the bibliometric study.

In the U.S. the same type of actors are relevant to involve. On the federal political level the Department of Education's International Affairs Office and the State Department are relevant counterparts. The Department of Education is responsible for international engagement in education and the State Department have overall responsibility for dealing with other countries and are for example the relevant counterpart for the national agreements on cooperation in education, research and innovation the Nordic countries have signed with the U.S.

Among the funders of research, the National Science Foundation (NSF) is a highly relevant partner. They had an annual budget of USD 7.5 billion in 2016 and one of their tasks is to support U.S. participation in scientific and educational activities. They have taken part in the current study and are positive towards increased cooperation with the Nordics. Given the high number of co-publications in health and medicine The National Institute of Health $(\mathrm{NiH})$ is also a relevant partner to involve. The $\mathrm{NiH}$ is under the U.S. Department of Health and Human Services and is the medical research agency of the U.S. NiH invests more than USD 32 billion a year in biomedical research. Since the public funding for research is being reduced in the U.S. these years it could also be relevant to involve large private funders of research. Representatives from American universities are also relevant to involve and could be invited based on who has the most co-publications with the Nordics. Johns Hopkins University, Berkeley University, University of Chapel Hill North Carolina and the U.S. Arctic Research Commission 
(USARC) have all contributed to this study and shown a strong interest in increased cooperation with the Nordics.

The study has also demonstrated that cooperation is very person dependent and often facilitated by individuals with a passion for both the U.S. and the Nordics. These individuals are important drivers of cooperation and often willing to contribute their time and resources to facilitate increased cooperation and can provide a very valuable contribution to increase cooperation.

What areas to focus on?

Most interviewees and participants in the workshop have agreed that the selection of focus areas should be a bottom-up process and not a top down process and have argued that the Nordic Council of Ministers should not exclude any research areas up-front.

At the same time, it has also been argued that focus areas should be aligned with national priorities. Thus, while it is not recommended that the Nordic Council of Ministers exclude any areas the concrete initiatives, funding mechanisms, calls etc. should to the extent possible be aligned with the research agendas of the Nordics and the U.S. The national research councils and the universities are well placed to provide input on the most relevant topics for them.

\section{Operational aspects}

In terms of the operational aspects we have divided the recommendations in overall guiding principles and concrete tools to increase cooperation between the Nordics and the U.S.

\section{Concrete tools}

A very large number of tools have been identified to increase cooperation between the Nordics and U.S. within higher education, research and innovation. They have been grouped under four headlines:

- Cooperation agreements at the political level. All the Nordic countries currently have agreements with the U.S. expressing a willingness to cooperate in higher education, research and/or innovation. While the Nordic countries generally value these agreements, it is unclear if a Nordic-U.S. agreement would add considerable value given all countries already have bilateral agreements;

- Cooperation agreements at the institutional level. The Nordic Universities cooperate frequently with the U.S. and have a variety of agreements with American universities. While agreements on student exchange is often at university level agreements on research cooperation is often at a decentral level and cooperation is often established on a researcher to researcher basis;

- Financing of cooperation. Providing funding for collaborative projects between researchers at Nordic and American universities seems an obvious tool to facilitate collaboration. The funding can take many different forms and can for 
example either fund networking and identification of common interest or the actual research;

- Information and marketing. Students and researchers often have a wide range of countries to choose between when they plan their stay abroad or search for international research partners and providing information on the opportunities in the Nordics and branding of the Nordics can therefore help attract American students and increase the awareness among American universities and researchers of the value of cooperating with the Nordics.

Since all the Nordic countries already have agreements with the U.S. and since the Nordic Council of Ministers' is perhaps not the most obvious counterpart for American universities the latter two instruments seem the most relevant for the Nordic Council of Ministers. However, the Nordic Council of Minister can sign agreements with American universities thereby opening options for cooperation for all the Nordic universities in a similar fashion as the Danish agreements with some of the most prestigious universities in the U.S.

\section{Overall guiding principles}

The inputs from the interviews and the workshops have formed the basis for developing some overall guidelines for the future work to increase cooperation within higher education, research and innovation:

- Do not duplicate existing efforts. Cooperation is already well-established and many valuable initiatives are already in place;

- Reciprocity is a key concept for success. Initiatives should be mutually beneficial to be sustainable in the longer run;

- Do not select topics up front. Future actions should not be prescriptive but should be aligned with Nordic and American priorities and the research community should be involved from the beginning;

- Successful cooperation is very person dependent. People who are enthusiastic about U.S.-Nordic cooperation are a valuable source for increased cooperation and leveraging their resources increases the chances of success;

- No one size fits all solution - different tools for different purposes. There are many different tools to promote cooperation in higher education, research and innovation and a variety of tools can be employed to increase cooperation depending on the objective and specific area;

- Build on existing structures, either:

- Nordic structures that are well-established and are ready to be opened up for further cooperation with the U.S., including NordForsk, Nordic Innovation, Nordplus and the Nordic Innovation Houses;

- Bilateral cooperation structures between a Nordic country and the U.S. which can be opened up for participation from the other Nordic countries. 
Proposals for concrete actions

The feasibility study has generated a number of proposal for concrete actions for the Nordic Council of Ministers. Since not all initiatives can be implemented immediately we have divided the suggested actions in short run and long run.

Generally, the initiatives that do not involve delegation of new authority to the Nordic level - but can be organised within the current structure, organisations and/or initiatives - and initiatives that do not involve large costs can be initiated in the shorter run whereas the proposals, which involve the creation of new organisations or large sums generally will take longer to implement.

Action which could be prioritised in the short run:

- Broaden the focus of some of the existing successful Nordic structures to include the U.S. As the main founder of joint Nordic research NordForsk is well-placed to open up some of their activities to include the U.S. This could be through pilot testing the Centers' of Excellence concept with participation from the U.S following the real common pot or virtual common pot principle or by establishing new funding streams (but this would require additional funding for NordForsk). Nordplus could play a similar role for mobility in higher education. The Nordplus programme offers financial support to educational cooperation between partners in the Baltic and Nordic region. Participants from other countries can be part of the program but cannot receive funding through the program. Nor can the programs activities take place outside the Baltic and Nordic region;

- Provide funding for testing successful national instruments for cooperation with the U.S. at the Nordic level. Nordic Innovation could provide initial funding for testing instruments similarly to what they are doing for the Nordic Innovation House in Silicon Valley. This would provide time to assess the value of the instruments and to raise national funding for the continuation of the successful instruments;

- Provide funding for networks of U.S. and Nordic researchers to identify common interests, develop proposals for joint research projects and help them identify potential funding sources. While it can be difficult to get new resources in the current climate initiatives which support networking are considerably cheaper than funding the actual research.

Actions which could be priorities in the longer run:

- Create a working group including representatives from the Nordic Governments, the national research councils and universities to explore the possibilities for cooperation further and to develop programmes and funding mechanisms for increased cooperation with the U.S: within higher education, research and innovation;

- Invite the main funders of research in the Nordic countries and the U.S. to workshops to identify common priorities and discuss programmes and funding streams which 
can be opened up for U.S-Nordic collaboration following either the real common pot or virtual common pot principle;

- Launch a call to inform about options to study and do research in the Nordics and to brand the Nordics as an attractive destination for students and researchers. Since many universities find it difficult to attract American students this could be a focus area;

- Enter into agreements with the most prestigious American Universities on behalf of the Nordic countries to offer American students and researcher a chance to study or do research at a Nordic University and for Nordic students and researchers to study or do research at prestigious American universities.

The majority of the above proposals are dependent on the Nordic Council of Ministers receiving funding from the Nordic countries to launch the activities. 


\section{Introduction and background}

This feasibility study explores the potentials for increased cooperation within higher education, research and innovation between the Nordic countries and the United States.

The Nordic countries - Denmark, Sweden, Norway, Finland and Iceland - have asked the Nordic Council of Ministers to investigate the potential for increased cooperation within research, higher education and innovation with the United States. The reason is that the Nordic countries are interested in strengthening the Nordic region's international competitiveness - as a leading region for knowledge and welfare.

A desire for further collaboration between the Nordic countries and the U.S. within higher education, research and innovation was also stressed in the declaration from 2016 "U.S. - Nordic Leader's Summit", which was signed by the Nordic prime ministers and the former President Obama. ${ }^{2}$

\subsection{Objective of the study}

Following this, the Nordic Council of Ministers has asked Oxford Research and the Confederation of Danish Industry to conduct a feasibility study to analyse the potentials for further cooperation, and to deliver a roadmap that describe the possible actions and next steps needed to increase cooperation between the Nordic countries and the U.S. within higher education, research and innovation.

More specifically, the study addresses the following questions:

- What is the current cooperation between U.S. and the Nordic countries within higher education, research and innovation?

- Which instruments and tools can be used to increase the Nordic-U.S. cooperation within higher education, research and innovation?

- What is the interest to increase the cooperation of higher education, research and innovation, and which focus areas is identified by the institutions in the Nordic countries and U.S?

- What is the added value for the Nordic countries to cooperation with the U.S on a Nordic level?

- What are the possible actions and next steps for further cooperation between the Nordic countries and the U.S. within higher education, research and innovation? 


\subsection{Scope and limitations of the study}

This study focuses on the Nordic-U.S. cooperation on higher education, research and innovation. Cooperation within these areas contain a wide variety of forms and means and it is therefore difficult, and perhaps not expedient, to draw a clear-cut distinction. The study has therefore focused on different forms and means of cooperation, including:

- Ordinary exchange agreements for students, including agreements for students with a research profile

- Cooperation between exchange agreements for scientific personal

- Research cooperation (e.g. joint research projects)

- Cooperation on innovation and commercialisation of research.

However, the scope of higher education, research and innovation are widespread and has therefore been circumscribed in order to clarify what the study includes and what the study does not include within the concepts of higher education, research and innovation.

Higher education

Higher education refers to an education at university level or similar educational establishment, especially to degree level, namely (university) college, business academies and/or arts/artistic educations. To narrow the scope of the study, we have limited the concept of higher education to "universities", which means that university hospitals, university college, business academia and similar are not included.

In the U.S., there are around 3,000 universities that offer university degree level education of at least four years. The focus in the U.S. has also been on "universities" (both public and private) and excludes for example "junior/community colleges".

\section{Research}

The study focuses on all forms of research, such as scientific, humanities, artistic, economic, social, business etc. that can be found within the scope of higher education. Private research and other types of research will therefore not be included in the scope of the study.

Innovation

Innovation is a widespread concept that is translated in different context. In this study, we focus on the transfer, exploitation and commercialisation of any research result that derives from the universities within higher education. Innovation fostered purely by private companies are therefore not included. 


\subsection{Methodology}

Three main sources of data have been used throughout the study:

- Desk research

- Qualitative interviews

- Workshop

The combination of the broad range of methods constitute a mixed methods approach that has the benefit of minimising the impact of idiosyncratic opinions and views of the different groups involved and, as such, strengthen the validity of the data.

\subsubsection{Desk research of existing cooperation}

Through partners in the U.S. and the Nordic region we have systematically carried out desk research to understand the current cooperation between the Nordic countries and the U.S. within higher education, research and innovation. Data collection on the cooperation has been carried out in three steps:

- Research on student exchange. The number of American students doing their entire education in the Nordic countries (university level), and the number of Nordic students doing their entire education in the U.S. (university level);

- Research on existing cooperation on the national level. Official agreements by governments to promote cooperation at university level with the U.S.;

- Research on examples of existing successful cooperation agreements at the university level. To identify "successful" agreements on student exchange and research collaboration we have contacted the international offices at a number of universities and asked them to provide information on their best examples of successful existing agreements they have with universities in the U.S.

Moreover, the study has included a bibliometric analysis by Science-Metrix. The analysis provide data on research cooperation between the Nordic countries and the U.S. within specific topics (presented in chapter 2).

\subsubsection{Interviews with key stakeholders in the Nordic countries and the U.S.}

Oxford Research and the Confederation of Danish Industry have conducted 76 qualitative interviews with stakeholders from political and university level.

The selection of relevant interviewees and the development of the interview guides was carried out by Oxford Research in Denmark in close collaboration with Oxford Research's partners in Sweden, Norway and Finland, and approved by the Nordic Council of Ministers. 


\section{Nordic countries}

63 interviews have been conducted in the Nordic region. They include the following representatives:

- $\quad 2-3$ interviews in each Nordic country at the political level with relevant representatives from the ministries of science and education, research councils and other public funding agencies. The interviews with ministries and agencies focused on official agreements, interest and potentials for increased cooperation on a political level.

- 8-10 interviews in each Nordic country at on the university level. The relevant universities were selected in close collaboration with the partners and in several cases two interviews were conducted at each university to cover the cooperation within student exchange, research and innovation.

- Moreover, three Nordic organisations based in the Nordics have been interviewed, including NordForsk, Nordic Innovation and Nordic Committee of Senior Officials for Education and Research (EK-U) within the Nordic Council of Ministers.

Oxford Research in Denmark has conducted the interviews in Denmark, Iceland and with the Nordic organisations. The partners in Sweden, Norway and Finland conducted the majority of interviews in their country, but Oxford Research in Denmark conducted two to three interviews in each country to get a good understanding of the situation in each country. A full list of interviewees can be found in appendix $C$.

\section{United States of America}

13 interviews have been conducted in the U.S with a variety of different actors. It has been difficult to reach all relevant political actors in the U.S., but we have conducted interviews with the Nordic embassies in the U.S., the Danish Innovation Centre in Silicon Valley, Tekes - The Finnish Funding Agency for Innovation in Silicon Valley, Innovation Norway in Silicon Valley, The Nordic Innovation House, the National Science Foundation and American universities. Further, a number of American actors took part in the workshop in Washington. A full list of interviewees can be found in appendix C.

\subsubsection{A joint Nordic-American workshop}

A central element of the data collection has been a joint Nordic-American workshop in Washington D.C that took place 23-24 May 2017. The workshop had two overall purposes:

- To discuss and validate preliminary conclusions and recommendations with relevant actors;

- To create a foundation for further cooperation to strengthen the Nordic-American cooperation within higher education, research and innovation. 
The workshop brought together key stakeholders from the Nordic countries (Denmark, Finland, Iceland, Norway, and Sweden) and the U.S., including government officials and representatives from higher education institutions and funding institutions. The workshop provided an opportunity for stakeholders to influence the process and efforts to increase cooperation between the Nordic countries and the U.S and to build networks with stakeholders across the Atlantic.

The workshop facilitated a fruitful discussion about the preliminary conclusions from the previous data collection, and also looked forward with key topics that was discussed in an interactive format combining group discussion and plenary presentation:

- How to increase cooperation between the U.S. and the Nordic countries?

- Added value - what are the benefits of organizing increased cooperation with the U.S. at the Nordic Level?

- Roadmap for increased cooperation - how to proceed? 



\section{Mapping of current cooperation}

This chapter will present the collected data on the mapping of current cooperation between the Nordic countries and the U.S. within higher education, research and innovation. First, the study by Science Metrix of Nordic-U.S. research collaboration ${ }^{3}$ will highlight the co-authorship of scholarly articles as a definition of collaboration, followed by an overview of some of the most interesting agreements and approaches for cooperation on national and university level within higher education, research and innovation.

\subsection{Cooperation in research}

Science-Metrix has conducted a bibliometric study of research cooperation between the Nordic countries and U.S. over the period 2006-2015 in the form of co-authorship of scholarly articles as a definition of collaboration, capturing one important facets of research partnership.

The study finds, that over the 2006-2015 period, there were over 20 million peerreviewed papers published worldwide. The United States participated in about 5 million of those (25\%), while the Nordic region participated in about 700,000 (1.5\%). Within the Nordic region, Sweden has the largest publication output (290,000 papers), followed by Denmark, Finland and Norway (145,000-175,000 papers each), and finally Iceland (10,000 papers).

3 Science Metrix (2017). Bibliometric assessment of Nordic-U.S. collaboration in research. 
Table 1: Publication output and international collaboration, across all research areas (2006-2015)

\begin{tabular}{|c|c|c|c|c|c|c|c|}
\hline \multirow[b]{2}{*}{ Country } & \multicolumn{4}{|c|}{ Overall } & \multicolumn{3}{|c|}{ Growth } \\
\hline & Paper & $\begin{array}{c}\text { Trendline } \\
\text { '06-'14 }\end{array}$ & $\begin{array}{l}\text { Intl. collab. } \\
\text { rate }\end{array}$ & $\begin{array}{c}\text { Avg. relative } \\
\text { no. of authors }\end{array}$ & Paper & $\begin{array}{l}\text { Intl. collab. } \\
\text { rate }\end{array}$ & $\begin{array}{l}\text { Avg. no. of } \\
\text { authors }\end{array}$ \\
\hline World & $20,560,499$ & annumbu & $34.0 \%$ & 1.0 & 1.3 & 1.1 & 1.0 \\
\hline United States & $5,129,334$ & 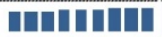 & $29.2 \%$ & 1.1 & 1.1 & 1.2 & 1.0 \\
\hline Nordic & 720,708 & manuman & $50.3 \%$ & 1.5 & 1.3 & 1.1 & 1.1 \\
\hline Sweden & 290,745 & mandung & $54.8 \%$ & 1.7 & 1.3 & 1.1 & 1.3 \\
\hline Denmark & 178,582 & mandu日an & $55.5 \%$ & 1.8 & 1.4 & 1.1 & 1.6 \\
\hline Finland & 153,115 & 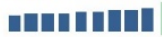 & $50.1 \%$ & 2.1 & 1.2 & 1.2 & 1.2 \\
\hline Norway & 144,261 & 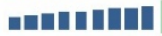 & $53.0 \%$ & 2.1 & 1.3 & 1.1 & 1.4 \\
\hline Iceland & 10,479 & 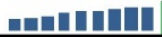 & $71.5 \%$ & 2.2 & 1.4 & 1.1 & 1.6 \\
\hline
\end{tabular}

Note: Publication output assessed using full counting. Publication output for 2015 not fully indexed in Scopus, so omitted for calculating growth in papers; growth of rates and averages include 2015 data. Colouring for averages, rates and indices ranges from red (lowest score, below index) through white (on par with index) to green (highest score, above index). For indicators without an index value, colouring ranges from white (lowest score) to green (highest score).

Source: Science-Metrix 2017.

Looking at the Nordic-U.S. collaboration across all areas of research, the U.S. publish about $2 \%$ of its papers in collaboration with a Nordic partner specifically (about $30 \%$ of its papers in collaboration with an international partner). The Nordic countries publish about $15 \%$ of their papers with a U.S. co-author specifically (about $50 \%-55 \%$ of their papers with international collaborators).

Table 2: Nordic-U.S. collaboration profile, across all research areas (2006-2015)

\begin{tabular}{|c|c|c|c|c|c|c|}
\hline \multirow[b]{2}{*}{ Country } & \multicolumn{3}{|c|}{ Overall } & \multicolumn{3}{|c|}{ Growth } \\
\hline & $\begin{array}{l}\text { Nordic-US } \\
\text { collab. rate }\end{array}$ & $\begin{array}{c}\text { Nordic-US } \\
\text { collab. index }\end{array}$ & $\begin{array}{c}\text { Nordic-US } \\
\text { collab. affinity }\end{array}$ & $\begin{array}{l}\text { Nordic-US } \\
\text { collab. rate }\end{array}$ & $\begin{array}{c}\text { Nordic-US } \\
\text { collab. index }\end{array}$ & $\begin{array}{c}\text { Nordic-US } \\
\text { collab. affinity }\end{array}$ \\
\hline United States & $2.0 \%$ & 1.0 & 0.7 & 1.3 & 1.0 & 1.0 \\
\hline Nordic & $13.9 \%$ & 1.0 & 0.7 & 1.1 & 1.0 & 1.0 \\
\hline Sweden & $14.8 \%$ & 1.0 & 0.7 & 1.1 & 1.0 & 1.1 \\
\hline Denmark & $15.9 \%$ & 1.0 & 0.7 & 1.2 & 1.0 & 1.1 \\
\hline Finland & $12.8 \%$ & 1.0 & 0.6 & 1.2 & 1.0 & 1.1 \\
\hline Norway & $14.1 \%$ & 1.0 & 0.7 & 1.1 & 1.0 & 1.0 \\
\hline Iceland & $24.5 \%$ & 1.0 & 0.8 & 1.2 & 1.0 & 1.2 \\
\hline
\end{tabular}

Note: Colouring ranges from red (lowest score, below index) through white (on par with index) to green (highest score, above index). For indicators without an index value, colouring ranges from white (lowest score) to green (highest score).

Source: Computed by Science-Metrix using data from Scopus (Elsevier).

Another measure of cooperation is the so-called collaboration affinity scores, which indicate if two countries collaborate more or less than expected. The expected output is based on the propensity of each partner to participate in international collaborations, and the size and collaboration intensity of the global research community more broadly.

As seen in table 2, the Nordic countries collaborated with each other much more than expected using this indicator, about $3-4$ times more than expected for most pairs of Nordic countries, and 5-7 times for Iceland in its partnership pairs. 
As for the U.S., its affinity scores with the Nordic countries range from $0.6-0.8$ and collaboration is therefore consistently below the expected value (a score of 1 indicates the collaboration is as expected). This is also the case for the U.S. affinity scores with other European states such as the Netherlands, Germany, France and the United Kingdom.

There were about 100,000 Nordic-U.S. collaborations over the study period; this represented about $65 \%$ of the expected Nordic-U.S. output (about 147,000 papers).

\section{Table 3: Collaboration affinity scores for Nordic countries and U.S., across all research areas (2006-2015)}

\begin{tabular}{|c|c|c|c|c|c|c|c|c|c|c|c|c|}
\hline & Nord & DK & $\mathrm{FI}$ & $\mathrm{IE}$ & NO & SE & FR & $\mathrm{DE}$ & NL & UK & $\mathrm{CN}$ & US \\
\hline Nordics & $\mathrm{N} / \mathrm{C}$ & $\mathrm{N} / \mathrm{C}$ & $\mathrm{N} / \mathrm{C}$ & $\mathrm{N} / \mathrm{C}$ & $\mathrm{N} / \mathrm{C}$ & $\mathrm{N} / \mathrm{C}$ & 0.9 & 1.1 & 1.4 & 1.1 & 0.5 & 0.7 \\
\hline DK & $\mathrm{N} / \mathrm{C}$ & $\mathrm{N} / \mathrm{C}$ & 2.8 & 6.6 & 4.4 & 3.6 & 1.0 & 1.3 & 1.8 & 1.2 & 0.5 & 0.7 \\
\hline $\mathrm{FI}$ & $\mathrm{N} / \mathrm{C}$ & 2.8 & $\mathrm{~N} / \mathrm{C}$ & 5.1 & 3.1 & 4.0 & 1.0 & 1.2 & 1.5 & 1.1 & 0.5 & 0.6 \\
\hline IE & $\mathrm{N} / \mathrm{C}$ & 6.6 & 5.1 & $\mathrm{~N} / \mathrm{C}$ & 7.7 & 5.4 & 1.2 & 1.0 & 1.9 & 1.4 & 0.3 & 0.8 \\
\hline NO & $\mathrm{N} / \mathrm{C}$ & 4.4 & 3.1 & 7.7 & $\mathrm{~N} / \mathrm{C}$ & 4.2 & 1.0 & 1.0 & 1.8 & 1.2 & 0.4 & 0.7 \\
\hline SE & $\mathrm{N} / \mathrm{C}$ & 3.6 & 4.0 & 5.4 & 4.2 & $\mathrm{~N} / \mathrm{C}$ & 0.9 & 1.1 & 1.5 & 1.1 & 0.5 & 0.7 \\
\hline \multicolumn{13}{|c|}{ Other Euro } \\
\hline FR & 0.9 & 1.0 & 1.0 & 1.2 & 1.0 & 0.9 & $\mathrm{~N} / \mathrm{C}$ & 1.0 & 1.1 & 0.9 & 0.4 & 0.6 \\
\hline DE & 1.1 & 1.3 & 1.2 & 1.0 & 1.0 & 1.1 & 1.0 & $\mathrm{~N} / \mathrm{C}$ & 1.4 & 0.9 & 0.4 & 0.7 \\
\hline NL & 1.4 & 1.8 & 1.5 & 1.9 & 1.8 & 1.5 & 1.1 & 1.4 & $\mathrm{~N} / \mathrm{C}$ & 1.3 & 0.4 & 0.7 \\
\hline UK & 1.1 & 1.2 & 1.1 & 1.4 & 1.2 & 1.1 & 0.9 & 0.9 & 1.3 & $\mathrm{~N} / \mathrm{C}$ & 0.6 & 0.7 \\
\hline \multicolumn{13}{|l|}{ Other } \\
\hline $\mathrm{CN}$ & 0.5 & 0.5 & 0.5 & 0.3 & 0.4 & 0.5 & 0.4 & 0.4 & 0.4 & 0.6 & $\mathrm{~N} / \mathrm{C}$ & 1.1 \\
\hline US & 0.7 & 0.7 & 0.6 & 0.8 & 0.7 & 0.7 & 0.6 & 0.7 & 0.7 & 0.7 & 1.1 & $\mathrm{~N} / \mathrm{C}$ \\
\hline
\end{tabular}

Note: Colouring ranges from red (lowest score, below index) through white (on par with index) to green (highest score, above index).

Source: Science-Metrix 2017.

The expected collaboration rate does not take into account such things as geographical distances, cultural differences and existing research infrastructure, such as funding of joint research. Given the geographical distance and the fact that the U.S. very rarely collaborate through Horizon $2020^{4}$ and previously FP6 and FP7, it is not surprising that collaboration is lower than what would have been expected from countries' participation in international cooperation generally.

As indicated in table 2, the share of U.S. papers produced with a Nordic co-author increased by about $30 \%$, while the share of Nordic papers produced with a U.S. coauthor increased by just over 10\% over the period from 2006-2010 to 2011-2015.

\footnotetext{
4 Horizon 2020 is open to participants from the US but they are encouraged to seek funding from research and innovation funding organisations in the US for their own participation in Horizon 2020. No jointly agreed mechanism is in place for cofunding Horizon 2020 research and innovation projects. In certain areas, it is flagged that US participation adds value and is encouraged. On 17 October 2016, The European Commission and the Government of the United States of America agreed to simplify the cooperation between Horizon 2020 projects and US entities. The US had 514 participants in 410 signed FP7 grant agreements, with a total EU contribution of EUR 81.96 million.
} 


\subsection{Agreements between the US and the Nordic countries within research, higher education and innovation}

At the university level, the total number of agreements for cooperation between the U.S. and the Nordic countries are very vast, and with a large degree of overlap in content. Moreover, collaboration is often organised at a decentral level by individual researchers agreeing to cooperate with peers. Therefore, no one at most Nordic universities have a complete overview of the total number of agreements with U.S. universities. This complicate the process of mapping the cooperation between the Nordics and the U.S. within higher education, research and innovation.

The existing agreements identified in this study have a large degree of overlap. Instead of presenting each agreement the emphasis in this section is on presenting interesting examples of cooperation and diversity of cooperation framework and actors.

On a general note, the cooperation between the U.S. and the Nordics is characterised by political agreement supported by personal relations. A tendency observed across the different kinds of agreements and the actors participating. There are also no strict borders between the areas of higher education, research and innovation. These areas rather exist in extension and support of one another.

Agreements can exist both at a national and university level. Below, we first provide an overview of cooperation at the national level between the Nordics and the US and then at the university level. In Appendix A, a summary of the existing cooperation for each Nordic country is presented, along with a short summary of existing cooperation.

\subsubsection{Cooperation on the national level}

National agreements on a bilateral level exist between the US and all the Nordics countries within research. These agreements are predominantly political and represent a national intention to cooperate further. They do not, however, contain financial support or represent legal tools for fostering further cooperation as such. The bilateral agreements are supported by cooperation on a national level, which extends beyond the political frame. These are national agreements, where the emphasis is practical rather than political. Such agreements are made between different actors, where at least one party is national. These actors can both be governmental and private, yet operate within a national setting. The Danish Ministry of Higher Education and Science has for example made agreements with universities in the U.S., which illustrates bilateral cooperation with the participation of a governmental actor. The Fulbright Commission is also operating on a bilateral level between the U.S. and each Nordic country, but is still a non-governmental actor existing within a national setting.

Higher education

While bilateral agreements on research collaboration exist, there are no active bilateral agreements focused on higher education between the U.S. and the Nordic countries.

The sole non-active example of a bilateral cooperation agreement within higher education is "The Finland-America Educational Trust Fund", which was established in 
1976 by the Ministry of Education in Finland and the American Embassy. The agreement was established to give new sources of funding to ensure the FinnishAmerican academic exchanges. According to the interviewee from the Finnish Ministry of Education, the agreement is not in use today, since cooperation is predominantly based on personal relations and mostly operate on the institutional level at the universities. In Denmark, The Danish Council for Independent Research has made an agreement with the National Science Foundation in the U.S. on the research programme Graduate Research Opportunities Worldwide (GROW). The programme supports Masters and PhD students exchange and participation in research cooperation, and the council provides a monthly scholarship of DKK 24,300 along with further financial assistance to cover other expenditures related to the stay.

A non-bilateral national actor is the Fulbright Commission, which is sponsored by the U.S. Department of Education and each Nordic Ministry of Education. In Finland, the contribution to the budget by governmental actor however only amount to approximately $20 \%$. Other actors such as private foundations provide the remaining of the funds. The Fulbright Commission of Finland was also turned into a foundation in 2016. While the Fulbright Commission is present in all Nordic countries, it plays a more significant role in Finland and Iceland. The importance of Fulbright as in actor in these countries, can be found in the absence of governmental initiatives to foster the cooperation. Their work has thus filled the vacuum within this area. The financing of cooperation is enabled through several different scholarships aimed at students at all levels of higher education - from bachelors to PhD level. Scholarships mostly exist for Nordic students to study in the US. However, some scholarships also exist for US students, who wish to take part of their degree in Finland. The Fulbright Foundation does not operate within specific thematic areas, and the scholarships are available to all applicants.

Other similar national, yet non-governmental initiatives also exist. Examples hereof are the Norway-American Association and Denmark-America Foundation, which provides scholarships for studies in the US.

Research

The study finds that all Nordic country have signed bilateral agreements on research collaboration with the U.S., and that other national initiatives further support this area.

Finland was the first Nordic country to sign a bilateral agreement on research of science and technology with the U.S. in 1995. Norway signed a similar agreement in 2005, Sweden in 2006 and Denmark in 2009. In 2006, Iceland also signed a Memorandum of understanding, declaring a mutual interest in increased cooperation.

As explained by a Nordic interviewee from the governmental level, the agreements were fostered by a U.S. initiative to establish a political framework for collaboration within science and technology with the Nordic countries. Overall, the agreements provide such framework, but not detailed specification of funding and specific focus areas of research.

However, Sweden has since extended their political agreement, through the introduction of several agreements of cooperation within more specific areas and with 
more tangible goals, such as an agreement for space research in 2006/ renewed in 2015, homeland security in 2007, arctic research in 2006 / renewed in 2015, and cancer research in 2005 / renewed in 2016.

The bilateral agreements between Sweden and the US, provide a political frame for collaborating more within specified areas, but the agreements are still limited to frameworks without the provision of legal or financial tools for further fostering collaboration. The Swedish interviewee on the governmental level also point out that the agreements support collaboration, but are not the driving force behind the collaboration between Swedish and U.S. within research.

Research collaboration that is supported by agreements can also take various other forms. Norway collaborate for example with the U.S. on research within the INPART, and Utforsk program, while Denmark collaborate with the U.S. through the International Networks Programme. Both programmes provide funding for networking, travelling and other activities with the purpose of facilitating increased cooperation.

Another type of national agreement on research collaboration can be seen in Denmark where the agreement is signed between the Danish government and University of California's (UC) Center for Information Technology Research in the Interest of Society (CITRIS), and center for SUstainable eNergy through CATalysis at the University of Stanford (SUNCAT).The agrements are presented in more detail in chapter 4 .

There are several of other agreements between the Nordic countries and the U.S. In addition to international student exchange, the Fulbright Programme is for example an important agreement for research collaboration. The programme provides scholarships for researchers and teachers to go to the US, and travel grants and a scholarship programme to attract American scholars to the Nordic countries.

\section{Innovation}

A variety of national initiatives exist within innovation, to foster the collaboration between the U.S. the Nordic countries.

The Nordic Innovation House in Silicon Valley is a joint Nordic initiative to help start-ups access the American market and plug the Nordics start-up community into the entrepreneurial ecosystem in Silicon Valley. The Nordic Innovation House developed from a Norwegian to a Nordic initiative to further the Nordic presence in the U.S. Innovation Norway initiated the project in 2011, and in 2014 it was expanded to a collaborative project between all the Nordic countries funded by the relevant Nordic government agencies, and predominantly support entrepreneurship and innovation. An example of a Nordic Innovation House initiative is REACH.

REACH is an incubator programme under the Nordic Innovation House, supporting Nordic research projects within technology, though with an international commercial interest. The programme has developed from the Norwegian Innovation House, and is thus an example of a national programme 
being expanded to Nordic level. The programme last six months, and support participants through the process of developing a research project into a business strategy.

Based on the success of the Nordic Innovation House in Silicon Valley and the REACH programme, it was agreed in early 2017 to supplement the initiative with another Nordic Innovation House in New York City.

Similar to the concept of a Nordic Innovation House, Denmark has established a Danish Innovation Centre in Silicon Valley and stationed an innovation attaché at the Center. The Innovation Attaché supports Danish researchers from universities and companies to connect to the research and innovation community in Silicon Valley and the rest of America.

Finland has made a national agreement with the University of California, Los Angeles (UCLA), which combined higher education and innovation. The agreement ensures that Finnish students can gain a place at the university. The agreement however supplements the educational aspect, through inclusion of collaboration between the students and Finish companies. This collaboration entails that the Finnish students might gain experience and support Finnish commercial internalisation, through simultaneous cooperation with companies on how to enter the US markets.

Another national initiative is the Norwegian Gründerskolen, which introduce higher education students to innovation and entrepreneurship tools.

Gründerskolen in Norway, is a national programme supporting the connection between higher education and innovation. The programme is a summer school supplemented with a 10-week internship in entrepreneurship in Silicon Valley. It was developed under the University of Oslo, but however exist in cooperation with Innovation Norway and is directed to all Norwegian students at an institution for higher education. Gründerskolen doesn't operate exclusively in Silicon Valley, and some years students have also been to Singapore, Beijing and Mexico.

Finally, the study show that private foundation also has established agreements with the U.S. within higher education, research and innovation. One example is the Danish Lundbeck Foundation that has made a programme "Clinical Research Fellowship", which allow medical students at master's level to study and simultaneously develop their expertise within clinical research and innovation. The programme exists in cooperation with the Danish Ministry of Education and the Danish Innovation Centre in Silicon Valley. 


\subsubsection{Cooperation at university level}

There are many agreements between the U.S. and the Nordic countries that support the exchange of students and researchers, and the research and innovation collaboration. Especially when it comes to collaboration between highly specialized researchers it is generally more relevant to enter into agreements directly between researchers (or institutes) than between universities.

Higher education

All the Nordic university have official agreements of student exchange with one or more universities in the U.S. Differences however exist in the number of agreements in place and the organisational and practical framework. The desk research on student exchange agreements show that a university can have up to 43 agreements with different universities in the U.S, including both public and private universities, small and large universities and some of the best ranked universities in the world such as Stanford, MIT, Harvard, UC Berkeley and more.

The agreements all exist on faculty or university level, but many in the interviews have also pointed out that non-official agreements exist on a researcher-to-researcher level, which the international offices at the university doesn't always know about or are involved in.

While the study shows that there is a great number of exchange agreements, it is stressed by many universities that the agreements sometimes suffer from an unbalance of exchange students between the U.S. and the Nordic university. The agreements are often based on a 1:1 exchange approach, but it is often difficult to find a matching American student due to the lower demand for exchange to the Nordic Universities. This dissymmetry is based on several factors:

- Financing is the major obstacle for U.S. students. Their degrees are often very expensive, and this limits their opportunities to and interest in traveling abroad;

- Structural differences in relation to higher education is another important obstacle. For example, will U.S. students often not be able to take the necessary courses for their degree while going on exchange. Most courses offered in English is at master's level, and U.S. students most often go on exchange on their bachelors;

- Expectations and cultural accommodation is another aspect mentioned by informants. Nordic students are often older and more self-sufficient than their U.S. counterparts. Higher education in the U.S. is further often private, while it is public in the Nordic countries. As U.S. students arrive on exchange, they often have different expectations for support and accommodation. An example of this is U.S. student dorms on campus, which is often unavailable in the Nordics; 
The difficulties in attracting American students for exchange has according to several of the universities, resulted in termination of agreements with US Universities. An exception to this is the agreement between the University of Copenhagen and the University of Wisconsin, with whom the University of Aarhus also have an agreement.

Both the University of Copenhagen and the University of Aarhus in Denmark, characterise their agreement with the University of Wisconsin as the most successful. The University of Copenhagen thus report having sent 15-25 students a year since 1987, while the University of Aarhus report sending 10-20 students a year. The agreements are described as being successful, due to the Danish cultural heritage in Wisconsin, and the academic compatibility orchestrated by the Department of Scandinavian Studies in Wisconsin.

Some Nordic universities have addressed the challenges by establishing short-term exchange agreements through summer schools. The University of Jyväskylä in Finland for example attracts around 20 American students every year to take a semester, and around 40 students yearly to the summer school through the international students exchange programme, ISEP. The University of Helsinki also have good experiences with the framework of the ISEP network. Short term exchange agreements, are however also made bilaterally between universities though these are often organised unsymmetrically. The University of Aarhus has for example established AU Summer University, where courses are offered in English. The exchange is then unsymmetrical in the sense, that as three students participate in the programme, it will allow the University of Aarhus to send one student on ordinary exchange in return. Buffalo State University will then often send 30 students to participate in Aarhus, which in returns allow the university to send 10 students.

Copenhagen Business School has developed an elite Bachelor's degree "GLOBE" in cooperation with the University of North Carolina and the Chinese University of Hong Kong. Students on this programme spend one semester at each University, and the degree thereby institutionalise cooperation and exchange. Copenhagen Business School also offers summer schools and have been successful in attracting American students to these.

\section{Research}

While some official research agreements exist between the Nordic and U.S. universities, most research collaboration is decentralised and takes place from a bottoms-up level.

The collaboration within research generally does not materialise from official agreements between universities. Individual researchers are instead the initiators and carriers of collaboration within this area. Some Nordic universities however report, that relations from such collaboration are occasionally consolidated through official agreements of cooperation. The Universities however also report that the central administration is often unaware of the existence of agreements and cooperation taking place between individual researchers. Therefore, a complete overview of these research agreements does not exist. 
While the vast majority of research collaboration takes place on decentral level, some agreements of research collaboration at the university level exist. These agreements are primarily Norwegian and American universities. The Norwegian Research Council has for example signed a research agreement with the University of California, Berkeley on behalf of nine Norwegian universities. This collaboration is facilitated by The Peder Sather Centre for Advanced Study, which works to strengthen the cross-Atlantic institutional research cooperation on all thematic areas of research.

The University of Oslo has facilitated several other agreements. One such example is the cooperation with the University of California, San Diego within brain research. The cooperation within this area was established in 2013 within a pilot project on "strategic educational partnership". A request from the University of California has since been made to extent the cooperation to the remaining of the universities under the UC system.

The operation within networks is also a valuable tool for Nordic Universities for research cooperation with American Universities. Copenhagen Business School has for example been invited by Yale University, to become partners in the "Fox International Fellowship".

A concern for the development of cooperation within research is funding. The interviewed stakeholders often address their concerns on the lack of funding for research collaboration and exchange with other international universities. Third parties may however often assist financially. Fulbright for example financially supports exchange of researchers between Finnish and US Universities, in collaboration with the universities themselves.

Innovation

Agreements pertaining to innovation at university level is limited. The existing examples of cooperation often exist in extension of other initiatives, or with the support of national initiatives.

Few official agreements exist within the area of innovation on the university level. The universities are predominantly preoccupied with furthering cooperation within higher education and research, since these aspects relate to their primary tasks of existence. The existing cooperation within innovation often involve collaboration with US universities being on the forefront within a certain field. Cooperation between universities within innovation is thus based on need for expertise within commercialisation and private collaboration.

The Kungliga Tekniska Högskolan (KHT) in Sweden has for example an ongoing cooperation with Stanford University, which is further supported by the Nordic Innovation House. In overall, the Nordic Innovation House as well as the Danish Innovation Centre are important governmental initiatives that can facilitate agreements on the university level. The interviewee report, that there is an increasing interest in cooperation, but that development of cooperation within this area is often based on personal relations.

Other approaches to cooperation in innovation rather emphasise the commercial aspect of innovation. The University of Agder have thus established a research-based 
centre for innovation in mechatronics. The cooperation with US companies is integral, since the university is developing unique technology which can be applied and further developed in the U.S. The cooperation has however experienced some challenges and cultural differences. For example in relation to the Protection of Intellectual property, where the approach of U.S. private businesses is different from the approach of a Nordic university, which predominantly emphasise publications of knowledge. 



\section{Interest in increased Nordic-U.S. cooperation}

In the study, we have examined the interest in increased Nordic-U.S. cooperation within higher education, research and innovation from a political and university level, as well as the different stakeholder's reflections on within which areas there is potential to increase cooperation and which institutions and organisations that are most important within the identified areas.

\subsection{Political level}

There are many concrete initiatives and statements that indicate a strong governmental interest to increase the cooperation between the Nordic countries and the United States within higher education, research and innovation.

One of the most significant proof of this is the declaration from May 2016 "U.S. Nordic Leader's Summit", which stress a desire for greater cooperation in the field of higher education, research and innovation.

"The Nordic countries and the United States have always enjoyed intensive people-to-people contacts and exchanges. We share a joint desire to boost these contacts further and to enhance collaboration in innovation, higher education and research."

(U.S. - Nordic Leaders' Summit Joint Statement, 13 May 2016)

The joint statement from the meeting in the White House emphasises some of the most important shared global priorities between the Nordic and the U.S., including security and defence; migration and refugees; climate, energy and the Arctic; economic growth and global development. The vision to boost the collaboration further, as stressed in the statement, is explicitly highlighted in the matters of Arctic research. Within the Arctic, the countries encourage further cooperation between higher education institutions and society. Moreover, the Nordic countries welcome a new initiative on a political level from the U.S. administration in the White House, namely the White House Arctic Science Ministerial. This initiative took place shortly after the summit meeting, and brought together ministers of science, chief science advisors, and other high-level officials from countries around the world to expand joint collaboration focused on Arctic science.

Another importance point in the joint statement is the cooperation within digitisation and sustainable production where the U.S. and the Nordic countries together will promote innovation through the Nordic Innovation House in Silicon Valley. As 
elaborated in the previous chapter, the Nordic Innovation House provides a "soft landing spot" for entrepreneurs in the highly competitive Silicon Valley.

As emphasised in the interviews and during the workshop with participants from the Nordic countries and the U.S., the Nordic Innovation House as well as the Danish Innovation Center in Silicon Valley are signs of strong interest to expand the collaboration within different areas of research and innovation with the U.S. In addition, the Nordic ministries of higher education and research have recently decided to open a new Nordic incubator and soft-landing spot for Nordic entrepreneurs in New York City, which also underline the strong interest to strengthen the U.S. - Nordic cooperation within research and innovation.

Stakeholders on the political level, also indicates a strong interest to increase collaboration with the U.S. However, some stakeholder also questions the specific focus on the U.S. and argue for a wider international outlook in general. In Finland for example, one of the objectives in the Government Programme, according to the policy advisor, is to raise the level of internationalisation within higher education and science in general and not explicitly targeting the U.S. However as explained in the interview, "the cooperation with the American research institutions are of course an important priority due to the institutions' high-quality of education and international cutting-edge research". It is recognised across the different stakeholders from the Nordic countries, that the American research and innovation community is leading within many scientific fields and therefore an attractive partner to strengthen the countries competitiveness within higher education, research and innovation.

From the funding agencies and research council's perspective, it is stressed that internationalisation is a core element in their research and innovation strategies. The specific collaboration with the U.S. is perceived as important, however, the stakeholders also stress that cooperation between Nordic-American researchers must always be motivated by the individual research's interest, and not just by political interests. In this connection, some research agencies in the Nordic countries also question the idea of new funding initiatives focused on the U.S. The funding organisations have generally experienced budget cuts and thus needs to prioritise the research projects and other activities they support. The Nordic countries and the funding schemes already allocate a relative high part to European cooperation, primarily under Horizon 2020, which is the Nordic countries primary international commitment.

\subsection{University level}

In line with the results from the political level, the study also indicates a strong interest to increase the U.S. - Nordic cooperation within research and exchange of students and researchers. However, the interest varies across the universities as some find it more attractive to strengthen to collaboration with the U.S. than others. The tendency is that large universities often have the strongest international outlook and interest to increase the collaboration. 
For the individual university, the benefits from increasing their international activities are more or less clear, as cooperation exposes those institutions to new knowledge, finance opportunities and better can attract talented students and researchers. The Nordic universities see the American universities as interesting partners due to the resources they have available and the high quality of their research. Also, the cultural barriers are seen as small since students and researchers from the Nordics have good language skills and a similar tradition for independent research as American researchers.

Another view that is shared across the universities in the Nordic countries is an interest to strengthen the collaboration agreements that exist with the partner universities in the U.S. due to the unbalanced flow of exchange students. As illustrated in appendix A, approx. 7,300 fewer students were exchanged from an American university to a Nordic university in 2014 compared to students from the Nordic countries taking degrees in the U.S. The high tuition fees in the US are highlighted by several as a barrier for persuading US students to study in the Nordics. The US students are focused on what they get for the tuition fee, which is often uncertain for the US students if they go to the Nordics, due to their lack of familiarity with the Nordic Universities. Also, US students might not get full credit for their courses in the Nordics at their American University. Finally, US students also pursue exchanges as part of their bachelor degree, where the availability of courses in English is often limited at Nordic Universities compared to master level.

As the demand for exchange positions in the U.S. is greater than the supply of students, the Nordic universities stress an interest in prioritising fewer agreements with U.S. students in the future in order to balance the flow of exchange students.

Despite the unbalance of exchange students between the U.S. - Nordic universities, the study indicates a strong interest from the universities in the U.S. to strengthen the collaboration with universities in the Nordic countries. The Nordic stakeholders in the U.S. experience the interest from American universities in the Nordics as high and Nordic research and education is regarded as being of very high quality.

A survey initiated by the Danish Ministry of Higher Education in 2015 support these findings. The survey explores the interest from universities in U.S. to collaborate with Danish higher educational institutions. Based on 250 universities in the U.S., of which approx. $40 \%$ answered the questionnaire, $78 \%$ showed a high degree of interested to be contacted by the Danish institutions in order to establish a collaboration on exchange of students. The responses from the U.S. institutions also indicate interest to collaborate more to strengthen the exchange of scientific staff and research collaboration that can help increase the mobility among students. 5 These findings indicate a potential to further strengthen the mobility of students and researchers between the Nordic countries and the U.S.

5 Ministry of Higher Education and Science, 2015. 


\subsection{Focus areas of further cooperation within research and innovation}

While the study shows that there is a strong interest to collaborate more intensely between the Nordic countries and the U.S., the interviewees and participants in the workshop have also pointed out that the focus areas of increased collaboration should be of mutual interest, as explained by the representative from the National Science Foundation in the U.S.

"If the Nordic countries could define areas of common interest, for example the Arctic region, and if they could bring the necessary funding to the table, NSF would be interested in entering into a regional collaboration with the Nordic countries."

(Interview with NSF)

As indicated in this study by different stakeholders, research collaboration is largely played out at the individual/personal level. In order to increase the collaboration more intensively, the specific focus areas of further collaboration therefore have to be motivated by the researchers themselves in a bottom up approach. It is therefore difficult, and potentially damaging, to prescribe the specific topics for further collaboration within higher education, research and innovation.

The following section will instead point to broad focus areas of interest, based on the data available in this study, including the different stakeholder's perceptions of areas of interest as well as the findings from the bibliometric analysis.

\section{Arctic research}

One of the most obvious focus areas of interest is the Arctic cooperation and interdisciplinary research collaboration between human, social, natural and health science within the Arctic research.

The Arctic is a polar region that mainly consist of the Arctic Ocean, and parts of Alaska (U.S.), Canada, Finland, Greenland (Denmark), Iceland, Norway, Russia and Sweden. Research in the Arctic has long been a collaborative international effort in the fields of environment, transport, energy, maritime safety and more.

The mutual beneficial interest for a more intense research collaboration between the Nordic countries and U.S. is strong due to their geographical location in the Arctic region. Arctic research as a potential focus area of cooperation is emphasised across all stakeholders in the study.

While the interest in Arctic research is strong, it is at the same time a very small area compared to health and medicine in terms of publication output (approx. $0.3 \%$ of the 20.5 million publications produced at the world level across all areas of research). However, the U.S. collaborates with a Nordic partner on $10 \%$ of its publications, relative to $2 \%$ of U.S. publications for all areas of research combined, and the Nordic region also 
collaborates with the U.S. on about $20 \%$ of its publications (about $50 \%$ higher than their collaboration rate with the U.S. overall).

Table 4: Nordic-U.S. collaboration profile, arctic research (2006-2015)

\begin{tabular}{|c|c|c|c|c|c|c|}
\hline \multirow[b]{2}{*}{ Country } & \multicolumn{3}{|c|}{ Overall } & \multicolumn{3}{|c|}{ Growth } \\
\hline & $\begin{array}{l}\text { Nordic-US } \\
\text { collab. rate }\end{array}$ & $\begin{array}{l}\text { Nordic-US } \\
\text { collab. index }\end{array}$ & $\begin{array}{c}\text { Nordic-US } \\
\text { collab. affinity }\end{array}$ & $\begin{array}{l}\text { Nordic-US } \\
\text { collab. rate }\end{array}$ & $\begin{array}{l}\text { Nordic-US } \\
\text { collab. index }\end{array}$ & $\begin{array}{c}\text { Nordic-US } \\
\text { collab. affinity }\end{array}$ \\
\hline United States & $10.2 \%$ & 5.2 & 0.7 & 1.2 & 0.9 & 1.1 \\
\hline Nordic & $20.3 \%$ & 1.5 & 0.7 & 1.1 & 1.0 & 1.1 \\
\hline Denmark & $24.2 \%$ & 1.5 & 0.7 & 1.3 & 1.1 & 1.2 \\
\hline Finland & $16.2 \%$ & 1.3 & 0.5 & 1.2 & 1.0 & 1.1 \\
\hline Iceland & $31.5 \%$ & 1.3 & 0.8 & 1.2 & 1.0 & 1.2 \\
\hline Norway & $18.6 \%$ & 1.3 & 0.6 & 1.1 & 1.0 & 1.1 \\
\hline Sweden & $26.2 \%$ & 1.8 & 0.7 & 1.1 & 0.9 & 1.1 \\
\hline
\end{tabular}

Note: Colouring ranges from red (lowest score, below index) through white (on par with index) to green (highest score, above index). For indicators without an index value, colouring ranges from white (lowest score) to green (highest score).

Source: Science Metrix 2017.

Some key institutions for the Nordic-U.S. partnership in arctic research include University of Alaska Fairbanks, NOAA, NASA, the University of Washington and the University of Colorado at Boulder. On the Nordic side, the University of Copenhagen, Stockholm, Oslo, Aarhus and Bergen are key institutions in terms of number of publications within arctic research.

Moreover, intuitions such as U.S. Arctic Research Commission (USARC) that have participated in this study, The Arctic Council that is an important intergovernmental forum for cooperation among the Arctic States, the White House Arctic Science Ministerial that was initiated in September 2016 and will have their next ministerial meeting in the Fall, 2018 in Berlin are all important actors in the area of arctic research.

Life science, health and medicine

Life science, health and medicine is a massive research area worldwide. Both the U.S. and the Nordic countries is globally recognised as leader within medicine and life science, which is partly reflected in a high publication output, and a strong industry with a number of leading global companies, which is sustained by massive investment in innovation and R\&D.

The life sciences pervade many aspects, including health care, medicine, agriculture, pharmaceutical, agriculture and the food science industries. There is considerable overlap between many of the topics of study in the life sciences.

Furthermore, the Nordic countries are not only an attractive partner due to its competencies but also due to the relatively small populations, possibilities to do clinical trials and the data registers, the existence of a social security number for all citizens, 
which is attractive for research worldwide, because it makes possible to follow people and their health over time.

As illustrated in the bibliometric analysis, the U.S. and the Nordic countries produce a larger share of their publications in health and medicine research than the worldwide average. The U.S. participated in about 2.3 million publications ( $45 \%$ of all U.S. publication output) and the Nordic countries participate in about 300,000 publications ( $41 \%$ of all Nordic output).

Table 5: Nordic-U.S. collaboration profile, health and medical research (2006-2015)

\begin{tabular}{|c|c|c|c|c|c|c|}
\hline \multirow[b]{2}{*}{ Country } & \multicolumn{3}{|c|}{ Overall } & \multicolumn{3}{|c|}{ Growth } \\
\hline & $\begin{array}{l}\text { Nordic-US } \\
\text { collab. rate }\end{array}$ & $\begin{array}{c}\text { Nordic-US } \\
\text { collab. index }\end{array}$ & $\begin{array}{c}\text { Nordic-US } \\
\text { collab. affinity }\end{array}$ & $\begin{array}{l}\text { Nordic-US } \\
\text { collab. rate }\end{array}$ & $\begin{array}{c}\text { Nordic-US } \\
\text { collab. index }\end{array}$ & $\begin{array}{c}\text { Nordic-US } \\
\text { collab. affinity }\end{array}$ \\
\hline United States & $2.1 \%$ & 1.1 & 0.7 & 1.3 & 1.0 & 1.0 \\
\hline Nordic & $16.1 \%$ & 1.2 & 0.7 & 1.2 & 1.0 & 1.0 \\
\hline Denmark & $17.2 \%$ & 1.1 & 0.7 & 1.2 & 1.0 & 1.1 \\
\hline Finland & $16.1 \%$ & 1.3 & 0.6 & 1.2 & 1.0 & 1.0 \\
\hline Iceland & $31.7 \%$ & 1.3 & 0.9 & 1.4 & 1.1 & 1.3 \\
\hline Norway & $15.9 \%$ & 1.1 & 0.6 & 1.2 & 1.1 & 1.1 \\
\hline Sweden & $17.2 \%$ & 1.2 & 0.6 & 1.2 & 1.1 & 1.1 \\
\hline
\end{tabular}

Note: Colouring ranges from red (lowest score, below index) through white (on par with index) to green (highest score, above index). For indicators without an index value, colouring ranges from white (lowest score) to green (highest score).

Source: Science Metrix 2017.

Both the Nordic countries and the U.S. is globally recognised as leaders within life science, which is reflected in world leading life science and medicine universities such as Harvard University, NIH, Johns Hopkins University, University of Pennsylvania, University of California, San Fransico in the United States. From the Nordic region, Karolinska Institutet, University of Copenhagen, University of Oslo and Lund's University are recognised as key players.

\section{Environmentally friendly solutions, Cleantech}

The area of clean energy and environment has been highlighted in many of the interviews by different stakeholders. This focus area is interesting for many stakeholders in the Nordic region and in the U.S. due to the Nordic countries energy policy and long tradition of developing and adopting high environmental standards. Moreover, many of the Nordic companies are at the forefront of the technology. The focus area is therefore perceived as a Nordic stronghold, which is interesting for many research communities in the U.S. that focus on clean energy and energy efficiency improvements.

Cleantech refers to any research or innovation process that leads to reduced negative environmental impacts through energy efficiency improvements, the sustainable use of resources, or environmental protection activities. 
While the collaboration outcome of research publications in the area of environmentally friendly solutions and cleantech is below average and for clean energy the bibliometric analysis, the study still indicates that there is room for improvement due to the relative strong research community in the Nordic region.

Table 6: Nordic-U.S. collaboration profile, environmentally friendly solutions \& cleantech research (2006-2015)

\begin{tabular}{|c|c|c|c|c|c|c|}
\hline \multirow[b]{2}{*}{ Country } & \multicolumn{3}{|c|}{ Overall } & \multicolumn{3}{|c|}{ Growth } \\
\hline & $\begin{array}{l}\text { Nordic-US } \\
\text { collab. rate }\end{array}$ & $\begin{array}{c}\text { Nordic-US } \\
\text { collab. index }\end{array}$ & $\begin{array}{c}\text { Nordic-US } \\
\text { collab. affinity }\end{array}$ & $\begin{array}{l}\text { Nordic-US } \\
\text { collab. rate }\end{array}$ & $\begin{array}{c}\text { Nordic-US } \\
\text { collab. index }\end{array}$ & $\begin{array}{c}\text { Nordic-US } \\
\text { collab. affinity }\end{array}$ \\
\hline United States & $1.8 \%$ & 0.9 & 0.6 & 1.6 & 1.2 & 1.1 \\
\hline Nordic & $8.0 \%$ & 0.6 & 0.6 & 1.1 & 1.0 & 1.1 \\
\hline Denmark & $10.2 \%$ & 0.6 & 0.6 & 1.2 & 1.0 & 1.2 \\
\hline Finland & $7.2 \%$ & 0.6 & 0.6 & 0.9 & 0.7 & 0.8 \\
\hline Iceland & $15.4 \%$ & 0.6 & 0.7 & 2.0 & 1.7 & 2.7 \\
\hline Norway & $9.4 \%$ & 0.7 & 0.6 & 1.4 & 1.3 & 1.3 \\
\hline Sweden & $7.2 \%$ & 0.5 & 0.5 & 1.1 & 1.0 & 1.1 \\
\hline
\end{tabular}

Note: Colouring ranges from red (lowest score, below index) through white (on par with index) to green (highest score, above index). For indicators without an index value, colouring ranges from white (lowest score) to green (highest score).

Source: Science Metrix 2017.

Looking at the Nordic-U.S. collaboration profile, as illustrated above, the collaboration in terms of publications is less intensive than across research in general, as the index values are below 1.o. However, in terms of changes from 2006-2010 and 2011-2014, the collaboration has been increasing intensity, meaning that the Nordic countries individually have increased their collaboration with the U.S., especially Iceland, and Norway.

Cooperation on clean energy was also stressed as a priority in the U.S.-Nordic Leader's Summit meeting, including a financial contribution of USD 2.3 million from the Nordic countries and the U.S. to establish a multilateral secretariat for support for new initiatives and campaigns. It indicates that there is potential to increase the collaboration even more intensely.

On the Nordic side, DTU - Technical University of Denmark is the largest producer of publications in cleantech research, following by Lund University, NTNU, KTH and the University of Aarhus. In the U.S. research in environmental solutions and clean technologies is dominated by Department of Energy (DOE) and Department of Agriculture (USDA), followed by U.S. Environmental Protection Agency (EPA). Regarding Nordic-U.S. co-authorship specifically, the DOE, UC Berkely and Ohio State University from the U.S. and DTU from the Nordic region stands out as drivers of collaboration. 


\subsubsection{Other research areas of interest}

The study has comprised a large amount of data from stakeholders with different perspectives and own interest within their specific specialities and competencies. The above-mentioned focus areas are primarily stressed as interesting areas of further collaboration by the stakeholders that have been interviewed and/or participated in the workshop. In addition, some other areas of interest have also been emphasised. Not only by the stakeholders but also by the bibliometric analysis on co-authorships.

While space research is only mentioned a few times as an area of interest by the stakeholders in the study, looking at the co-authorship collaboration, space research is an area in which Nordic-U.S. collaboration is notably more intensive than their collaboration patterns overall. The Nordic-U.S. partnership is much stronger in space research than it is overall. The U.S. collaborate with the Nordic region twice its normal rate, and the Nordic region collaborate about three times its normal rate. Some institutions that emerge as key for Nordic-U.S. collaboration in this area of research specifically include NASA, Caltech, the Smithsonian Institution, and KTH in Sweden.

Beyond space research, information communication technologies (ICT), fishery and agriculture, and food are all areas of some interest, as it is mentioned by different stakeholders in the study. However, looking at the co-authorship collaboration, it is areas of less intense collaboration. 


\section{Tools to increase cooperation}

This chapter explores tools to increase cooperation within higher education, research and innovation.

\subsection{Tools}

The desk research, interviews and workshop in Washington have provided a variety of examples of tools to increase cooperation within higher education, research and innovation. Some of the examples have been utilised to promote cooperation at the Nordic level but most have been used to promote bilateral cooperation between one of the Nordic countries and the U.S., but is equally relevant at a Nordic-U.S. level.

The examples have been divided into four overall categories of instruments:

- Cooperation agreements at the political level

- Cooperation agreements at the institutional level

- Financial support

- Information and marketing

\subsubsection{Cooperation agreements at the political level}

It is often seen that countries sign agreements stating an intention to cooperate within higher education and/or research and/or higher education. The Nordics doesn't have a common agreement with the U.S. but all the countries have individual agreements with the U.S. The agreements are described in further details in chapter 2 and in the appendices.

The agreements are often fairly short and doesn't reserve funding for cooperative activities. Still, however, the Nordic actors emphasise that these agreements are important as symbols of the good relations between the countries within higher education, research and innovation and because they establish the necessary structures to handle any barriers for cooperation quickly. At the same time, it is unclear what added-value a Nordic-U.S. agreement would provide given that all the countries already have agreements with the U.S. 
Example of cooperation agreements at the political level between the U.S. and Norway

Agreement on science and technology cooperation between the Government of the Kingdom of Norway and the Government of the United States of America

In 2010 the U.S. and Norway signed an agreement to cooperate within science and technology. The agreement constitutes a formal framework for cooperation and establishes some overall principles for and forms of cooperate between the two countries.

The agreement obliges both countries to establish a national contact point to maintain contact between the two countries and to meet to discuss cooperation upon request from either country.

The agreement doesn't reserve any funding for cooperation but states that cooperative activities is subject to the availability of appropriated funds, resources, and personnel.

Declaration on Educational Exchange Between the Government of the United States of America and the Government of the Kingdom of Norway

In 2007 Norway and the U.S. also signed a Declaration on educational exchange aiming to stimulate the collaboration in higher education and research by enhancing and facilitating mobility of students and faculty and seeking to encourage, develop and facilitate cooperative activities.

The agreements are generally very simple and mainly establishes an intention to cooperation and often nominate a contact person in each country involved and a forum to discuss common priorities and challenges which hinder cooperation.

\subsubsection{Cooperation agreements at the institutional level}

Agreements at the institutional level is also an often used tool to promote cooperation within higher education, research and innovation. The agreements can for example focus on student and researcher mobility or joint research projects. Examples of institutional cooperation is also described in chapter 2 and in the country appendices.

The traditional form of institutional level cooperation is university to university agreements to collaborate. As mentioned these are especially useful to promote student exchange and is often based on 1:1 mutual exchange.

Agreements at the institutional level can also take various other forms. Agreements can also be signed between a country and a university. Examples of this includes Denmark's agreements with Stanford University, CITRIS at Berkeley and MIT.

Example of cooperation agreements between Denmark and American Universities

Examples of agreements between a country and universities

Denmark has agreements with Center for Information Technology Research in the Interest of Society (CITRIS), SUstainable eNergy through CATalysis (SUNCAT) at Stanford University and Massachusetts Institute of Technology (MIT), who host Danish Ph.D. students and Postdocs. for 3-12 months. Danish Agency for Science, Technology and Innovation pays the slotting fee for the researchers to become a visiting scholar and a stipend for travel costs but the researcher is responsible for financing salary, accommodation, insurance etc. The agreements are part of an overall strategy to strengthen relations between Danish and American Universities. 
Agreements can also be between faculties, institutes or individual researchers. Since research cooperation is often highly specialised the agreements are often decentralised, whereas it makes more sense to enter into student exchange agreements at the university level.

As also mentioned in chapter 3 it is a challenge for many of the Nordic Universities to attract as many American students as they are able to send to the U.S. Since the agreements are often 1:1 agreements this limits the number of students the Nordic universities can send to the U.S. To accommodate the reluctance of American students to spend entire semesters in the Nordics - thereby not being able to participate in semesters in the U.S., which they have paid a very high tuition for - some Nordic Universities have started offering summer schools for foreign students, including American students. So far experience indicates that this is an effective tool to attract more American students to the Nordics. Some respondents have also pointed out that more courses in English at bachelor level can help attract more American students as they most often seek exchanges as part of their bachelor degree.

Creation of Nordic Research Centres in the U.S. or American Centres in the Nordics is an additional tool to promote cooperation. Stanford University in California for example has SCANCOR, a Scandinavian Consortium for Organisational Research, which supports working visits and residencies for Nordic Scholars at Stanford and Harvard Universities. ${ }^{6}$ The workshop in Washington revealed that researchers at University of Berkeley and Johns Hopkins University would like to host Nordic centres at their universities and the Nordic Innovation House have been discussing, if they could offer "soft landing spot" facilities for researchers like they do to businesses. Similarly, American universities could be attracted to the Nordics to offer education there. Opening of centers is a good way to institutionalise cooperation and build long-term relationships since the centers are not as person dependent as the exchange agreements for example can be. They also require considerable more resources than just establishing an exchange agreement between two universities and therefore also more preparatory work and commitment.

\section{Examples of a Nordic Center in the U.S - SCANCOR}

SCANCOR, a Scandinavian Consortium for Organizational Research, was established in 1989 at Stanford's School of Education following many years of intense collaboration between Nordic scholars and Stanford University. In 2016 SCANCOR opened an additional site at Weatherhead Center for International Affairs at Harvard University

SCANCOR facilitates inquiry in organizational social science among a transnational network of scholars. Its member institutions in the Nordics (and greater Europe) support working visits and residencies at Stanford and Harvard Universities. SCANCOR is mainly funded by Nordic universities. In 2016 SCANCOR at Stanford University welcomed 36 Visiting Scholars and Visiting Student Researchers and one new Postdoctoral Fellow.

\footnotetext{
${ }^{6}$ http://www.scancor.org/
} 


\section{On-going work to open Nordic Centers in the US}

For the last five years the Center for Transatlantic Relations/SAIS Johns Hopkins University (JHU) has been developing a project called "Nordic Ways". SAIS has held numerous conferences, seminars, discussions on the topic of the Nordic countries on very diverse topics: security, innovation, equality, Nordic-cooperation in general. This has lead to the editing and publishing in 2016 of a book of essays by the same name, "Nordic Ways" in close cooperation with the Nordic Council of Ministers

They are now in the process of establishing a long term presence of "Nordic Ways Studies" at SAIS Washington D.C. The "Nordic Center" will be an independent entity embedded in the Johns Hopkins University System and SAIS. It will be a center of research, analysis, education and training, a platform for the Nordic countries to have more visibility in political Washington, but also the framework for a Nordic Studies Program. The Center will partner with Universities and research centers in the Nordic Countries.

Robert Strand, Executive Director \& Lecturer at the Center for Responsible Business, University of California-Berkeley, Haas School of Business is likewise working on the establishment of a Nordic Sustainable Innovation Center at a leading U.S. academic institution, such as UC-Berkeley. Such a center would serve as a U.S.-based hub and resource for Nordic firms and academics to develop the Nordic region and its firms as recognized global leaders in sustainable innovation. In addition, the center would work to raise the worldwide profile of the Nordic region and Nordic firms as global sustainability leaders while further developing a deeper understanding for the supporting factors. This includes further development of the "Scandinavian Cooperative Advantage" concept that describes the comparative advantage of Nordic firms for effective cooperation. The center would also serve as a resource for Nordic interests based in U.S. to cultivate further interest for collaboration and engagement between U.S. and Nordic entities.

The agreements to cooperate doesn't have to focus strictly on formal education and research but can also include a focus on innovation. The cooperation agreements with universities in Silicon Valley, in particular, often have built-in elements of entrepreneurship and innovation, where students or researchers combine their stay at a University in California with an internship at a start-up or courses in entrepreneurship and innovation. The Nordic innovation House and the Danish Innovation Center in Silicon Valley are often partners in these programs since they focus on innovation and entrepreneurship and have comprehensive networks with important actors in the local ecosystem.

\section{Example of cooperation that includes a focus on innovation}

Examples of cooperation that includes a focus on innovation

The Nordic Countries have a number of exchange programmes which in addition to research and education also focus on innovation. An example is already mentioned Norwegian program "grunderskolen" (the founder's school). The program consists of a 10 week internship at UC Berkeley in California, where the students attend classes and a fulltime internship at a local start-up (see also chapter 2).

Another example is the REACH, a program under the Nordic Innovation House in Silicon Valley. REACH is a 6-month program enabling research-based innovation projects to identify commercial applications by introducing them to the Silicon Valley eco-system and useful start-up tools and models, 
pairing them with mentors and setting up meetings with industry experts, potential customer, partners and investors and helping them identifying a viable route to market. The program started as a Norwegian program but Sweden and Finland is today also part of the program (see also chapter 2).

The research for the report has demonstrated that the above-mentioned tools are often valuable instruments. In addition to the immediate effect of the cooperation - trying to live in another country, experiencing a different culture, collaborating with other researchers, etc. - they build important networks between the U.S. and the Nordics, which continue to exist after the researchers and students have moved back to their host university. Agreements to cooperate are very person dependent and often initiated by people who have a special relationship with the countries involved in the research. It could be a Nordic professor at an American university or an American university, who has been a visiting scholar at a Nordic University. Many of the examples mentioned in this report are initiated by such people.

\subsubsection{Financing of cooperation}

Providing funding for collaborative projects between researchers at Nordic and American universities is also a tool often used to facilitate collaboration. The funding can take many different forms.

Financing can be provided as "seed money" to explore possibilities for collaboration. This can for example take the form of financing of joint research symposiums between Nordic and American Universities to build networks and explore common research interests and potential for collaboration. The Danish Innovation Center in Silicon Valley can for example finance research symposiums between Danish and American researchers who would like to explore the potential for collaboration further.

Related to this is funding of more permanent networks and coordination of joint activities for researchers within a specific area (but not funding of the actual research). The purpose can be to explore mutual interests, develop joint proposals for funding or to prepare calls for proposals.

These two types of funding have the advantage of being able to support a relatively high number of activities for limited means since they do not support the actual research but only facilitates the networking, exploration of joint interests and development of proposals.

Further, cooperation can be facilitated by funding of joint research. Various models exist for this and are for example employed by the national research council's and similar actors, who fund research. The models are normally competitive and calls can for example be for research projects, research centres and professorships, and if often evaluated by a program committee or similar composed of experts in the relevant fields. NordForsk finance Nordic Research projects - mainly in the form of Centres of Excellence - which must have participation from at least three Nordic Countries (see text box 4 for further details). 
A simple way to internationalise funding of research is to oblige all bidders to include participants from the relevant countries, i.e. to say that all proposals must contain representatives from both the U.S. and more than one Nordic Country.

Funding of joint research can follow a real common pot or a virtual common pot principle. Under the real common pot principle each funding organisation provide funding for one or more joint calls and the funding is awarded to the best proposals irrespective of country origin. Thus, the funding organisation has no guarantee that the funding it provides will go to representatives from its own country. Under a virtual common put model each funding organisation will only fund successful participants from its own country. This funding mode enables national funding organisations to retain autonomy and control of their own national budget and of own funding decisions, and does not entail funding of non-nationals and/or non-residents. ${ }^{7}$

Example of finding of joint research - NordForsk
Examples of funding of joint research - NordForsk

NordForsk was established in 2005 as one of two pillars in NORIA (Nordic Research and Innovation Area). NordForsk's main instrument for supporting Nordic research collaboration is their Nordic Centres of Excellence. The Nordic Centres of Excellence are multi-site or single-site research environments with joint research agendas, joint management, coordinated researcher training, communication and research infrastructure cooperation. Funding are usually provided for five years following a competitive call and is in the range of EUR 2.5-5 million per centre. The formal applicant must be a legal entity based in one of the Nordic countries that co-fund the programme, the project consortium must involve partner institutions from at least three Nordic countries and the consortium must provide a cash or in-kind contribution towards the centre themselves.

Funding can also be provided for pilot testing new initiatives or joint activities. This model is often used in innovation policy, where funding is provided for a certain number of years for an instrument or initiative to demonstrate its value after which the initiative must be self-financing. Nordic Innovation has for example provided the initial financing for initiatives at the Nordic Innovation House in Silicon Valley. Once the financing from Nordic Innovation expires each Nordic country must provide financing for its continued participation. Similarly, instruments that promote cooperation with the U.S. successfully in one country can be opened up to participation from other Nordic countries and instruments that promote cooperation between the Nordic countries successfully can be opened up for U.S. participation.

During the interviews and the workshop in Washington it has been pointed out that it is much easier to build on already established Nordic structures for cooperation within higher education, research and innovation, which can be opened up for participation from the U.S. instead of having to agree on new structures.

7 https://www.era-learn.eu/manuals-tools/call-implementation/call-planning/call-process-and-administration/fundingmodes 
Funding opportunities can be closely related to institutional exchange agreements mentioned above for example by providing financing for mobility of researchers and students between Danish and American universities.

\section{Financing of student mobility}

Financing exchange of students and researchers - The Fullbright U.S. Student Program

The Fulbright U.S. Student Program offers research, study and teaching exchange between the U.S. and app. 150 countries to recent graduates and graduate students. The Program is the largest U.S. exchange program and more than 360,000 Fulbrighters from the United States and other countries have participated in the Program since its inception in 1946. The Fulbright Program awards approximately 8,000 grants annually.

The primary source of funding for the Fulbright Program is an annual appropriation by the U.S. Congress to the U.S. Department of State's Bureau of Educational and Cultural Affairs (ECA). Participating governments and host institutions, corporations and foundations in foreign countries and in the United States also provide direct and indirect support.

\subsubsection{Information and marketing}

Education and research is becoming increasingly international and students and researchers often have a wide range of countries to choose between when they plan their stay abroad or seek for international research partners. It is therefore essential that students and researchers know about the opportunities and competencies in the Nordic countries and the U.S.

One tool to attract international researchers and students is to inform about the options to study in the country. Most countries for example have "Study in" homepages informing about how you can study in the country, what you can study, where you can study, visa requirements, tuition, financing options, etc. These homepages will typically also have information about how it is to live in the country and student life, since these are also important parameters for many.

In addition, many countries use resources on marketing of the country to students and researchers. This is closely related to the above but whereas some initiatives and campaigns mainly inform about options, rules and requirements etc. others more directly try to attract students and researchers by marketing the country and its educational institutions. This can be done through advertising campaigns, by being present at international education conferences \& expos, etc.

While some have highlighted that it can be difficult for the Nordic Countries to conduct joint information and marketing campaigns because they - despite many similarities - have different strengths and messages they would like to communicate some have also highlighted that there is an obvious advantage of joint information and marketing activities, especially because:

- it is more resource efficient to finance marketing of the Nordics as a common entity than to finance marketing of each country individually; 
- many Americans are not aware of the differences between the Nordic countries but are familiar with the concept of the Nordic countries;

- the Nordic countries are very small in an American context whereas the Nordics is a much larger entity. It is therefore a more equal partner in many respects and offers a greater variety of options. 


\section{Nordic added value}

This part of the study examines the "Nordic added value", namely the justification for acting at the Nordic level, in relation to higher education, research and innovation. The Nordic added value is important for the Nordic Council of Ministers because cooperation should always bring extra value for the Nordic countries compared to working individually.

The Nordic actors that has taken part in this study have therefore been asked if they can see any added value or synergy effects of organising further cooperation with the U.S. at the Nordic level compared to organising it at the national level. In the following, we analyse all the inputs and explore the meaning of the Nordic added value within higher education, research and innovation, and how this can be organised, including which role the Nordic Council of Ministers could play as well as the national governments, universities and other relevant actors.

\subsection{The Nordic added value of enhanced cooperation with the U.S. within higher education, research and innovation}

There are many shared opinions on what the added value is to increase the cooperation with the U.S. on a Nordic level within higher education, research and innovation. Moreover, several initiatives and programs already exists in the Nordic region that add value for the Nordic countries, but very few of these activities are focused on collaborating with the U.S. within higher education, research and innovation. Therefore, some interviewees find it difficult to imagine what the Nordic added value is without being presented for a specific idea or model for further Nordic-U.S. collaboration.

Overall, most actors on both a political and university level see it as self-evident that Nordic cooperation adds value, especially for small countries like the Nordics, meaning that it will always bring new knowledge, capacity building and new funding opportunities of working together. However, other find the Nordic added value more challenging to realise because both public and private research institutions always want to stand out, for example to attract the best students and researchers from the U.S.

\subsubsection{Leverage the Nordic brand in the U.S.}

A view that is shared across all stakeholders is that the Nordic region holds some shared values that brand the Nordic region and its stakeholders around the world. In matters of Nordic added value, it is highlighted that the Nordics region are more attractive as a partner than the Nordic countries individually. Therefore, it is emphasised that 
countries should coordinate their branding activities towards the U.S. to raise the awareness of the Nordic values and attractiveness as a partner for the U.S.

This is especially an advantage when establishing collaboration with the most prestigious American universities, who receive many requests for collaboration. When a Nordic country or an individual university have their own branding activities it easily drowns in the stream of information in a large country like the U.S. and might not get the attention of some of the most prestigious and best ranked universities in the U.S.

In recent years under the auspice of the Nordic Council of Ministers, there has already been some effort to make Nordic brand more visible, for example in the Nordic Council of Ministers strategy on international branding of the Nordic region. ${ }^{8}$ As illustrated in the strategy and consolidated by some of the stakeholders in this study, the image of the Nordic region is positive around the world, largely because the Nordic countries share values such as openness, trust, innovation and sustainability. These shared values make the Nordic countries stand out because it is perceived as a solid foundation of further collaboration, including in the matters of higher education, research and innovation.

To leverage the Nordic brand, the values need to be translated into concrete branding initiatives and other activities in the context of a more intensive collaboration within higher education, research and innovation. As highlighted by the stakeholders, the Nordic Council of Ministers could take an active role to leverage the attractiveness as a partner for the U.S. by coordinate and facilitate new branding activities.

A setting in the U.S. where the Nordic Council of Ministers can brand the shared values and opportunities in the Nordic region within higher education and research is the yearly NAFSA Conference.

NAFSA Conference takes place in California, U.S. and brings universities and research institutions together from around the world to meet and share insights on all areas of international education administration, student services, research and teaching.

According to some of the stakeholders, the Nordic countries took part in a joint stand during the NAFSA conference for many years, but have chosen to represent themselves in recent years. On one side, this underline the challenges in practice to coordinate the branding activities because each Nordic country and university have their own interests. On the other hand, it also stresses the importance of the Nordic Council of Ministers taking an active role and trying to assist in develop marketing tools and activities that will inspire, help and facilitate the branding work for all stakeholders, who take part in and benefit from branding the Nordics.

Another idea that is highlighted in the interviews and during the workshop with different stakeholders is to initiate a joint information portal on the Nordic level that targets universities in the U.S., and support the attractiveness of students and

\footnotetext{
${ }^{8}$ Nordic Council of Ministers 2015, Strategy for International Branding of the Nordic Region 2015-2018.
} 
researchers to the Nordic region and universities. As stressed by the stakeholders, it is more interesting to access the whole Nordic region for the American students because the Nordic countries and universities are small by American standards, while the Nordic region is bigger, has more options and is more interesting.

For student exchange, the Nordic countries already have well-established and respected co-operation, such as the Nordplus programme. Nordplus generate added value for the Nordic countries by offering financial support to a variety of educational cooperation between partners in lifelong learning, including higher education between eight participating countries in the Baltics and Nordic region. Universities from other countries such as the U.S. can take part of the program but cannot receive funding through the program. Nor can the programs activities take place outside the Baltic and Nordic countries. As mentioned by stakeholders, it would strengthen the educational cooperation between the Nordic and U.S. if the U.S. was perceived as a stronger partner in the program and it was possible to use the program for increased student mobility between the U.S. and Nordic countries. As inspiration, the EU have a similar programme, Erasmust, which has the U.S. as a partner country.

\subsubsection{Critical mass in research excellence at the Nordic level}

The Erasmus Programme is an EU exchange student and staff programme that has been existing since 1987. It purpose is to provide foreign exchange options for students within the programme countries, namely the 28 EU Member States. However, Erasmus+ from 2014-2020 has opened up the same opportunities, allowing for mobility of students and staff, from and to other parts of the world, including the U.S. (so called Partner Country).

Another view on the Nordic added value perspective is that each Nordic country by itself lacks critical mass on a U.S. scale, but by pooling resources, funding and other activities, the Nordic region can enhance critical mass and benefits from the combination of different expertise and resources available in the different countries.

To investigate the potential for a stronger Nordic cooperation to enhance critical mass in research at Nordic level, we have asked each National Research Council in the Nordic countries, if they can see any advantages of organising and coordinating increased cooperation with the US at the Nordic level compared to organising it at the national level. In overall, they share the same interest to look at the possibilities to strengthen the collaboration with some of the public or private funding institutions in the US such as the National Science Foundation (NSF), the National Institute of Health $(\mathrm{NIH})$, the Department of Energy, the Department of Defence and NASA. However, the study also shows some degree of doubt or scepticism of organising increased collaboration with the US at the Nordic level. In one interview, the stakeholder mentions a current programme where the Nordic countries act as an entity on research collaboration with Japan, but the overhead costs are larger than the gained value of the agreement. Many of the National Research Councils have also in recent years seen cutbacks and have been forced to prioritise a national portfolio of well-functioning 
funding instruments. Therefore, some finds it difficult to prioritise new funding instruments towards a stronger research collaboration with the US.

Despite some degree scepticism, each of the stakeholders from the National Research Council in the study agree that they are interest to look at the possibilities of coordinating increased cooperation with the US at the Nordic level within certain areas of mutual interest. As already pointed out, the focus areas of increased collaboration should be aligned with areas which the National Research Council have highlighted as important in their research and innovation strategy.

In the following we have pointed at some possible approaches to enhance critical mass in research collaboration with the US at the Nordic level.

One approach in a smaller scale from a funding perspective is through seed-money, as explained in chapter 4 , where the funding does not necessarily cover the research itself, but the coordination and networking activities. As stressed by the stakeholders, seed-money can open doors for further networking activities that is crucial to build personal relations and trust between researchers.

Another more comprehensive approach, as stressed by the stakeholders, is through excellent research that is stressed by many of the stakeholders as important to generate added value and synergies for the co-operation. By focusing on research excellence, it provides better opportunities for the most skilled researchers in their field across the Nordic region to collaborate with other Nordic and U.S. researchers, and it opens the door to cooperation with a much larger critical mass of top researchers, contributing to the development of new knowledge and capacity building in the Nordic research institutions.

In the Nordic region, one of the most important funding instrument by NordForsk is the Nordic Centre of Excellence (NCOE), as explained in chapter 4, to increase and facilitate cooperation between excellent researchers, researcher groups or institutions in the Nordic country.

The example of the Nordic Centre of Excellence is stressed as an important approach to achieve added value of working together in the Nordic region because the approach means that both parties must bring something interesting and "state-of-art" research to the table. Thus, reaching the critical mass of research areas where the Nordic countries are highly specialised through initiatives such as the Nordic Centre of Excellence, it will more likely bring a greater spectrum of expertise to the U.S, which constitute fruitful cooperation. An evaluation concerning two research programmes using Nordic Centre of Excellence as financial instrument confirms the idea that schemes such as the NCoE are beneficial for already established groups of researchers who have pre-existing professional's relations and trust. 


\section{Sammenfatning}

Nordiska ministerrådets har formulerat en överordnad vision om ett synligt och utåtvänt Norden. Inom forskning och utbildning inriktas arbetet på att styrka de nordiska ländernas internationella konkurrensförmåga genom att skapa att en väl fungerande utbildnings-och forskningsgemenskap med internationella utländska miljöer av hög kvalitet. I detta sammanhang tillsatte Ministerrådet för forskning och utbildning en studie vars uppdrag är att kartlägga befintliga miljöer samt undersöka möjligheterna för ett ökat nordiskt-amerikanskt samarbete inom högre utbildning, forskning och innovation.

Oxford Research och Dansk Industri som utfört studien lämnade sin slutrapport November 2017. I denna ger de ett antal förslag till åtgärder både på kort och lång sikt samt diskuterar vilka aktörer, områden och konkreta verktyg som kan vara relevanta

att fokusera på för att öka samarbetet mellan Norden och USA inom högre utbildning, forskning och innovation.

Resultaten visar att samarbetet är redan väl etablerat, men att det samtidigt finns intresse och potential för ännu starkare samverkan. Överordnade rekommendationer för åtgärderna är att inte duplicera pågående arbete, att initiativen måste vara ömsesidigt gynnsamma, att olika instrument måste användas för olika områden samt att det är av central vikt att bygga på redan existerande strukturer. 



\section{Appendix A: Nordic country report on cooperation agreements with the U.S.}

This appendix provides a short overview of each Nordic country's cooperation with the U.S.

\section{Denmark}

While Denmark do not have a bilateral agreement on higher education with the U.S., Denmark has concluded bilateral agreements within research and innovation and also a national agreement directly with three U.S. universities.

No bilateral agreements exist between Denmark and the U.S. within higher education. A general agreement on cooperation in research of science and technology however exists with the U.S. The agreement was signed in 2009, and represent a common political ambition to increase the research collaboration. As a non-bilateral, national initiative, Denmark has also made agreements directly with U.S. universities focused on research. The agreements are made between the Danish Ministry of Higher Education and Science, and CITRIS at the University of California, SUNCAT at Stanford University and MIT. Research and innovation is supported by the Danish Centre of Innovation (ICDK) in Silicon Valley, established in 2006. The centre facilitates research collaboration and provide inspiration to help drive innovation from Danish research instututions and SME's with internationalisation in the U.S.

At the university level, the University of Copenhagen, the University of Aarhus and the University of Aalborg describe one of their most successful agreement as being with the University of Wisconsin. Universities in Wisconsin are being promoted as wellestablished and successful because the collaboration is based on Danish cultural heritage in Wisconsin, and thereby a sense of cultural connection to Denmark. There is also a Department of Scandinavian Studies at the University of Wisconsin, which makes Denmark and the Nordic region an attractive destination for students within this department.

The Danish Technical University (DTU) report that their successful cooperation is with the University of Wisconsin-Madison, Caltech and Johns Hopkins University. This agreement does not have a great volume of students participating, but is nevertheless based on a close cooperation. Unsymmetrical cooperation has been applied to the 
agreement with Johns Hopkins University, as they had faced problems sending students to DTU, due to the structural differences in the courses. This concern has been approached through a specialised "faculty-led study abroad programme" at DTU. The programme consists of a lecturer from Johns Hopkins University offering a short course in January for U.S. students, though Danish students at DTU may also participate. A full programme, will allow DTU to send three students to Johns Hopkins on exchange. The University of Southern Denmark describe their cooperation with Ohio University as the most successful, as this is an agreement which has developed from personal relations and has evolved since its establishment in the 1980s. The agreement thus started as cooperation within English studies, but has since expanded due to higher interest. The agreement is based on a University level contract, where the number of students are updated on a continuous basis. However, in recent years, approximately 4-5 students are received each year under this agreement.

\section{Iceland}

While Iceland has a memorandum of understanding on research they do not have any bilateral agreements on higher education and innovation with the U.S. The funding from RANNIS and the Fulbright Program are very important elements of the research collaboration with the U.S.

No bilateral agreement exists between Iceland and the U.S. within higher education or innovation. A general Memorandum of Understanding exist within research, which denotes a common intention and desire to develop cooperation between the two countries. The agreement was signed in 2006 and was thus undertaken around the same time as agreements between the U.S. and the other Nordic countries were made.

The Icelandic Center for Research (RANNIS) is an important national actor in Iceland, which works to support Icelandic research and fund high quality research projects. Since no other agreements or initiatives exist on a national level, the Fulbright Commission is the other major actor facilitating and financing cooperation within higher education and research. The commission offer several scholarships for Icelandic students. The Frank Boas Scholarship, award funds for graduate studies in International Law (LLM) at Harvard University for two students. The Cobb Family Fellowship award funds for graduate studies in any given field at the University of Miami, Florida. For researchers, a grant of 8000 USD is available to conduct research at a U.S. research institution within. Scholarships also exist to attract U.S. students and researchers to Iceland. The Fulbright Scholar programme thus supports U.S. researchers spending a semester at an Icelandic university. The InterCountry Travel grant and the Fulbright Specialist programme, provide short term assistance for researchers to stay at an Icelandic institution.

At University level, formal agreements only exist within higher education. The University of Iceland thus report, that their earliest agreement on student exchange was signed in 1982 with the University of Minnesota, and the tradition of student exchange is 
therefore well-established. The University send around 20 students to the U.S. yearly, and receive around the same number in return. It is suggested by the informant of the University of Iceland, that the ability to meet the demand and receive an appropriate number of students from the U.S. is due to the increasing popularity of Iceland as a destination.

The University of Reykjavik considers cooperation with U.S. universities a high priority, and considers that successful cooperation is dependent on the strength of the relation between universities. Therefore, they are emphasising the personal aspect of developing relations, which must support an official agreement between universities for it to be successful. No initiatives exist within innovation, but the University of Reykjavik emphasise this area as one of potential for further cooperation.

Cooperation between Icelandic universities and U.S. universities within research is decentralised, and based on personal relations. Some informal cooperation however exists with U.S. national actors. The University of Akureyri has supported visitors from NASA to travel to Iceland, which allowed research cooperation between NASA and Akureyri to be fostered.

\section{Norway}

While Norway do not have any bilateral agreements on higher education with the U.S., the Norwegian cooperation with the U.S. is characterised by a strong existing collaboration within higher education and research on both national and university level.

No bilateral agreement exists between Norway and the U.S. within higher education. Other national initiatives however exist on a multilateral level, which include both higher education, research and innovation. International partnerships for Excellent Education, Research and Innovation (INTPART) thus emphasise the integration of higher education and research, and takes place in a network including seven other partners. The programme has NOK 36 million allocated for 2017 from the Norwegian Ministry of Education and Research. The Partnership Programme with North America supports cooperation within higher education and innovation with the U.S. and Canada, and the purpose of the programme is to strengthen cooperation between universities in the partner countries. The programme emphasise innovation as it encourages nonacademic public and private actors to participate within projects as partners. The project guidelines states that funding for projects including such partners will be prioritised for at least half of the available funds, which emphasise this connection. The High North Scholarship is a programme allowing students at higher education in the U.S. and four other countries undergo studies in Norway within areas that relate to the North such as environmental studies. The total annual funds available are NOK 2 million. The Norway-America Association (NORAM) is a non-profit foundation working to strengthen the connection between Norway and the U.S. They provide different scholarships for both Norwegian students to go to the U.S. for studies, but also for U.S. 
students to go to Norway for studies. A scholarship also exists for Norwegian politicians to study in Washington and for Norwegian lecturers to go to the U.S.

Innovation Norway, is an agency promoting collaboration between Norway and the U.S. within research and innovation. It was established in 2011, but the work was successful enough to graduate a common Nordic initiative in 2014.

On University level, cooperation exists between the University of California, Berkeley and all Norwegian universities. This is facilitated through The Peder Sather Centre for Advanced Study, at the University of California, Berkeley, which aim to strengthen the cross-Atlantic institutional cooperation. The cooperation emphasises research cooperation, and is open to all thematic areas of research.

The University of Oslo has in collaboration with the University of California, San Diego developed a common PhD degree within Informatics, Geography and Social Science. The idea came from Simula Research Laboratory (SIMULA), and the Norwegian government granted in 2015 NOK 10 million to further develop the cooperation. Other research cooperation between the University of Oslo and the University of California, San Diego, emphasise brain research. The cooperation within this area was established in 2013 within a pilot project on "strategic educational partnership". A request from the University of California has since been made to extent the cooperation to the reminder of the UC system. The University of Oslo also collaborate with the University of Minnesota in collaboration with the Norwegian University of Life Sciences (Universitetet for miljø- og biovitenskab). The cooperation exists within all areas of research, though with special emphasis on areas such as renewable energy and environment studies. The cooperation includes an agreement on student exchange, though since 2009 the number of students from the University of Minnesota has grown significantly, while the number of students from the University of Oslo to Minnesota has stagnated. In total, the University of Oslo has around 40 agreements of student exchange with U.S. Universities, where the majority is targeted students at bachelor's level. There is no overview of the mobility of researchers, as such cooperation takes place decentralised.

The University of Tromsø report their best agreements of cooperation as being with The University of Alaska Fairbanks and the University of Alaska Anchorage. Both are bilateral agreements, with a high level of interests from students on both side of the Atlantic.

The University of Agder, has the most cooperation with the University of Nebraska, Omaha, both within education and research. They send 5-8 student every year and receive around $3-8$ students in return. The University also cooperate with Oregon State University, and has witnessed an increase of interest from students here. Further, cooperation exists with the University of Minnesota and California State University Northridge, East Tennesse State University and Minnesota State University Moorhead. 


\section{Sweden}

While Sweden do not have any bilateral agreement on higher education with the U.S., the research collaboration between Sweden and the U.S. is characterised by bilateral agreements on different focus areas.

No bilateral agreements exist between Sweden and the U.S. on higher education and innovation. Several bilateral agreements however exist within research. A general agreement on "Scientific and Technological cooperation" exist. This agreement provides the political framework for several other agreements between Sweden and the U.S. within research. These are: "Implementing arrangement for cooperation on cancer research", "Implementing arrangement for cooperative research and logistical activities in polar regions", "Framework agreement for cooperative activities in the exploration of outer space for peaceful purposes" and "Agreement on cooperation in science and technology for homeland security matters". These agreements address different areas of research, and provide a framework for which further cooperation can develop within.

On university level, the cooperation between the U.S. and Sweden is welldeveloped within higher education and research.

Stockholm University reports, that around 146 students go to the U.S. every year. The most popular destinations are New York, San Diego and Michigan University. Their most successful cooperation is however with the University of Illinois. The agreement started on the basis of personal relations, and is considered successful due to similarity in organization and courses, as well as good communications between institutions.

Uppsala University have agreements with 22 partner-universities in the U.S. Most of these are on bachelor's level, but some are also on master's level. The majority of the agreements were made in the 1990s, and with universities offering courses in Scandinavian studies. One of these are with the University of Illinois at Urbana Champaign, who has however also made agreements with five other universities within the Stockholm Area, and some level of competition has consequently arisen. They however send around 50 students to the U.S. every year, but receive twice as many applications as there are places.

Kungliga Tekniska Högskolan also have a close cooperation with the University of Illinois at Urbana-Champaign, which emphasise the connection between higher education, research and civic engagement.

Göteborg University has 15-20 agreements on student exchange with U.S. Universities. Comparably, Örebro University has 11 agreements. Lunds University has over 30 agreements where 10 is on a central level, and the remaining on faculty or institute-level. The one-faculty university -Karolinska Institut have several agreements of cooperation within research, which is uncommon as these agreements are generally decentral in their organization. One such agreement is the multi-lateral Matariki Network of Universities, of which the University of Darthmouth also participate. Karolinska Institute also have extensive cooperation with Rockefeller University, which include three different exchange programmes. The KI-NIH Doctoral Partnership 
Programme in Neurosciece, is a PhD programme made in collaboration with the U.S. National Institute of Health ( $\mathrm{NIH}$ ). The degree is given by the Karolinska Institute, but includes a minimum of 12 months spent in a laboratory by the $\mathrm{NIH}$.

\section{Finland}

While Finland do not have any specific bilateral agreement on innovation with the U.S., Finland has concluded some agreements with the U.S. on higher education and research that enable Finnish students and researchers to exchange and conduct joint research projects with the U.S.

No initiatives or agreements exist with emphasis on innovation. A bilateral fund between Finland and the U.S. was established in 1976 to administer the research collaboration. The fund is however not an active tool for collaboration, as this is mostly fostered and developed by universities themselves.

The Academy of Finland cooperates with the Finnish government to ensure a national strategic synergy, which has recently included a wish of greater internationalisation within research. The Academy of Finland also collaborate with the National Science Foundation (NSF) in the U.S. One such initiative from this cooperation, is the administration of a mobility scheme, which allow young U.S. researchers to visit Finnish institutions for $2-3$ years. Another initiative is within information and communications technology (ICT). The initiative support projects between U.S. and Finnish researchers, where both national actors fund their own researchers.

The Fulbright Foundation is a valuable tool to facilitate student exchange. Although the programme exists in over 150 countries, it is especially prominent in Finland, where the U.S. government only contribute with around $10 \%$ of the total budget. The Finnish government contribute a similar level. The reminder of the budget is financed by Finnish universities, private foundations, research institutions and private donors. Several scholarships are available here for Finnish students and researchers. These are aimed towards bachelor's level, masters and doctoral level, post-doc level and lecturing, professionals, teachers and experts, travel grant for research collaboration, and scholarship for universities. Finally, a scholarship for American citizens also exist. In 2016, 94 scholarships were granted to Finns and Americans.

The Finnish Centre for International Mobility has agreed in collaboration with the Finnish universities to set the goal of doubling the amount of U.S. students coming to Finland by 2020. A strategic desire thus exists within Finland to strengthen the cooperation with the U.S. within higher education.

On university level, the cooperation within research, predominantly follow the general pattern of decentralised organisation based on personal relations and interests. Some official agreement however also exists, which support cooperation between universities. 
The university of Helsinki for example have 2-6 researchers going on exchange to the U.S. every year, while one researcher is going to Helsinki from the University of California, Berkeley every year in exchange. This agreement is on University level, though some formalised agreements also exist on faculty level. The universities of Finland have several agreements with U.S. universities. Most of these agreements are in collaboration with non-elite, though geographically diverse institutions. A summer school programme however exists within the International Students Exchange Programme (ISEP), which the University of Jyväskylä and the University of Helsinki participate in. The University of Helsinki has further cooperated with Stanford since 2011 through participation in the Stanford Summer Session. The participation allows the University to send six students to participate every year.

The University of Jyväskylä has moreover arranged their own summer-school in cooperation with Baylor University. The summer school is based on a faculty cooperation within pedagogy, maintained through a contract on university level. However due to the problem of attracting U.S. students, the university offers summer school for four students, and in exchange send two students on semester exchange to Baylor University. 



\section{Appendix B: Exchange of students between the U.S. and the Nordic Countries}

This appendix presents the collected data on students from the Nordic countries taking a full degree education in the U.S. and data on American students taking a full degree education in the Nordic countries.

\section{Students from the Nordic countries in USA}

According to the data available, we can see that approx. 8,658 students from the Nordic region took a full degree in the U.S. in 2014. As indicated in the table below, the number increased dramatically from 2010 to 2011.

However, the data are not entirely comparable and contains some degree of uncertainty, thus cannot read uncritical. The reason for the difference methods is that is has not been possible to receive comparable data from the Nordic databases and Ministries of Higher Education.

Table 7: Nordic students taking a full degree in the U.S

\begin{tabular}{|c|c|c|c|c|c|c|c|c|}
\hline & & 2009 & 2010 & 2011 & 2012 & 2013 & 2014 & 2015 \\
\hline Denmar & & 325 & 336 & 371 & 387 & 414 & 414 & \\
\hline Sweden & & 2,585 & 2,893 & 3,188 & 3,556 & 3,854 & 4,167 & 3,719 \\
\hline Norway & & 1,013 & 1,255 & 1,441 & 1,650 & 1,849 & 2,096 & 2,096 \\
\hline Finland & & 350 & 370 & 371 & 393 & 438 & 445 & 448 \\
\hline Iceland & & 282 & 285 & 298 & 315 & 288 & 265 & \\
\hline Total & & 1,970 & 2,246 & 7,408 & 8,064 & 8,299 & 8,658 & 7,657 \\
\hline ote: & Denmark: & $\begin{array}{l}\text { Uddanne } \\
\text { master de }\end{array}$ & $\begin{array}{l}\text { Forsk } \\
\text { excl. Ph }\end{array}$ & niniste & FM), & s taki & Il bach & \\
\hline & Sweden: & $\begin{array}{l}\text { Universite } \\
\text { at higher }\end{array}$ & $\begin{array}{l}\text { slersäm } \\
\text { tion tha }\end{array}$ & $\begin{array}{l}t(U K A ̈) \\
\text { e been }\end{array}$ & trala St & $\begin{array}{l}\text { tödsnä } \\
\text { st } 3.5 \text { y€ }\end{array}$ & $\begin{array}{l}n(C S N \\
\text { riod (in }\end{array}$ & $\begin{array}{l}\text { lents } \\
\text { D). }\end{array}$ \\
\hline & Norway: & $\begin{array}{l}\text { Senter for } \\
\text { bachelor/r }\end{array}$ & $\begin{array}{l}\text { nasjona } \\
\text { er and } \mathrm{Pl}\end{array}$ & $\begin{array}{l}\text { g av ut } \\
\text { gree. }\end{array}$ & ing (SIU) & dents ta & a full & \\
\hline & Finland: & Center for & ational & lity (CIN & tudents & $g$ a full $b$ & lor or m & degree. \\
\hline & Iceland: & Hagstofa & (Sta & and & its & edu & & \\
\hline
\end{tabular}




\section{American students in the Nordic countries}

Compared to the number of Nordic students taking a full degree in the U.S., the number of American students going to the Nordic countries are much lower. In 2014 approx. 1,300 students from American universities travelled to a Nordic university, which is more than 7,000 fewer students. The table below also highlight that all Nordic countries except Sweden (and Iceland due to missing data) have received more American students from 2009/2010 to 2014/2015.

Similar to the data in the table above, the data are not entirely comparable and contains some degree of uncertainty, thus cannot read uncritical. The reason for the difference methods is that is has not been possible to receive comparable data from Nordic databases and Ministries of Higher Education.

Table 8: American students taking a full degree in the Nordic countries

\begin{tabular}{lccccccc} 
& 2009 & 2010 & 2011 & 2012 & 2013 & 2014 & 2015 \\
Denmark & 132 & 152 & 163 & 190 & 211 & 212 & 210 \\
Sweden & & & 176 & 193 & 104 & 135 & 118 \\
Norway & 361 & 390 & 442 & 492 & 528 & 529 & 578 \\
Finland & & 283 & 312 & 333 & 398 & 424 & 104 \\
Iceland & 493 & 825 & 1,093 & 1,208 & 1,241 & 1,300 & 906 \\
Total & & & & & & \\
\hline
\end{tabular}

Note: Denmark: Uddannelses- og Forskningsministeriet (UFM), Students taking a full bachelor or master degree (excl. PhD).

Sweden: Universitetskanslersämbetet (UKÄ) \& Centrala Studiestödsnämnden (CSN), Students at higher education that have been studiying for at least 3,5 year-period (incl. PhD).

Norway: Senter for internasjonalisering av utdanning (SIU), Students taking a full bachelor/master and PhD degree.

Finland: Center for International mobility (CIMO), Students taking a full bachelor or master degree.

Iceland: Hagstofa Íslands (Statistics Iceland), Students at higher education. 


\section{Appendix C: list of interviewees}

Table 9: Denmark

Name Type of organisation Interviewee

Styrelsen for Forskning- og Uddannelse

Agency

Danmarks Forsknings- og Innovationspolitiske Råd (DFIR) Council

Det Frie Forskningsråd

Dansk Institut for Internationale Studier (DIIS)

Council

Københavns Universitet

Council

Københavns Universitet

University

Århus Universitet

University

University

Syddansk Universitet

University

University

Copenhagen Business School (CBS)

University

University

Danmarks Tekniske Universitet (DTU)

Foundation

vo Nordisk Fond

Foundation

Karin Ilsøth Rasmussen

Karin Kjær Madsen

Jan Philip Solovej

Kristian Fischer

Poul Petersen

Pernille Winther

Mette Brandedburg

Stefan Knudsen

Thorkild AErø

Dorte Salskov-Iversen

Jeppe Duus Solriis

Lundbeck Fonden

Niels-Henrik von Holstein-Rathlou

Enno-Hoffmann-Dose

\section{Table 10: Sweden}

\begin{tabular}{lll} 
Name & Type of organisation & Interviewee \\
\hline Utbildingsdepartementet & Ministry & Mat Johnsson \\
Vetenskapsrådet & Agency & Sven Stafstöm \\
Stockholms Universitet & University & Elisabeth Idermark \\
Stockholms Universitet & University & Åsa Landes \\
Göteborgs Universitet & University & Hans Abelius \\
Uppsala Universitet & University & Stephanie Noroozy \\
Lund Universitet & University & Anne Messeter \\
Lund Universitet & University & Anneli Wiklander \\
Lund Universitet & University & Linus Wiebe \\
Kungl. Tekniska Högskolan & University & Åsa Carlsson \\
Kungl. Tekniske Högskolan & University & Erica Buck \\
Karolinska Institut & University & Anna-Lena Paulsson \\
Karolinska Institut & University & Johanna Diehl \\
Handelshögskolan I Stockholm & University & Salam Zandi \\
\hline
\end{tabular}

\section{Table 11: Norway}

\begin{tabular}{lll} 
Name & Type of organisation & Interviewee \\
\hline Kunnskapsdepartementet & Ministry & Ida Grobakken \\
Senter for Internasjonalisering av utdaning (SIU) & Agency & Linda Rutledal \\
Forskningsrådet & Agency & Berit Johne \\
Universitetet i Oslo & University & Solveig Aas \\
Norges teknisk-naturvitenskabelige universitet (NTNU) & University & Nina Elisabeth Sindre \\
Universitetet i Bergen & University & Nina Gry Stein \\
Universitetet i Tromsø & University & Pål Vegar Storeheier \\
Universitetet i Agder & University & Kerry Stephen Seiler \\
Universitetet i Stavanger & University & Celine Nygaard \\
Nord University & University & Monica Brobak
\end{tabular}


Table 12: Finland

\begin{tabular}{lll} 
Name & Type of organisation & Interviewee \\
Ministry of Education and Culture & Ministry & Tiina Vihma-Purovaara \\
Ministry of Education and Culture & Ministry & Birgitta Vuorinen \\
Fulbright & Foundation & Terhi Mölsä \\
Academy of Finland & Agency & Johanna Hakala \\
University of Helsinki & University & Minna Koutaniemi \\
Aalto University & University & Mari-Anna Suurmunne \\
University of Turku & University & Irinja Paakkanen \\
University of Eastern Finland & University & Anitta Etula \\
University of Oulu & University & Tytti Haapaletho \\
Tampere University of Technology & University & Mira Kauppinan \\
Tampere University of Technology & University & Ulla Siltaloppi \\
University of Jyväskylä & University & Tuja Koponen \\
University of Jyväskylä & University & Timo Taskinen \\
\hline
\end{tabular}

Table 13: Iceland

\begin{tabular}{lll} 
Name & Type of organisation & Interviewee \\
\hline Ministry of Education, Science and Culture & Ministry & Una Stand Vidarsdottir \\
The Icelandic Centre for Research (RANNIS) & Agency & Elisabeth Andrésdottie \\
The Icelandic Centre for Re-search (RANNIS) & Agency & Kristmundur Pór Ólafsson \\
Háskóli Íslands & University & Hula Proppé \\
Háskólinn í Reykjavík & University & Ari Kristinn Jónsson \\
Háskólinn í Reykjavík & University & Kristján Kristjánsson \\
Háskólinn á Akureyri & University & Guðrún Rósa Pórsteinsdóttir \\
Háskólinn á Akureyri & University & Aron \\
Háskólinn á Akureyri & University & Gunarson
\end{tabular}

Table 14: Nordic actors

\begin{tabular}{lll} 
Name & Type of organisation & Interviewee \\
NordForsk & Nordic cooperation & Gunnel Gustafsson \\
NordForsk & Nordic cooperation & Marianne Røgeberg \\
Nordic Innovation & Nordic cooperation & Hans Fridberg \\
Embedsmandskomité for uddannelse og forskning (EK-U) & Nordic cooperation & Eivind Heder \\
\hline
\end{tabular}

Table 15: United States of America

\begin{tabular}{lll} 
Name & Type of organisation & Interviewee \\
\hline $\begin{array}{l}\text { Tekes in Silicon Valley } \\
\text { Nordic Innovation House in Silicon Valley }\end{array}$ & Agency & Thuong Tan \\
Innovation Norway in Silicon Valley & Nordic cooperation & Paola Salomaa \\
Innovation Norway in Silicon Valley & Agency & Gro Dyrnes \\
Massachusetts Institute of Technology (MIT) & Agency & Elisabeth Smestad \\
Danish Innovation Center in Silicon Valley & University & Lars Frølund \\
National Science Foundation (NSF) & Agency & Jeppe Dørup Olesen \\
Wellesley College (written input) & Agency & Mangala Sharma \\
Berkeley University & University & Jennifer Thomas-Starck \\
Icelandic Embassy in the U.S. & University & Robert Strand \\
The Swedish Embassy in the U.S. & Ministry & Erlingur Erlingsson \\
The Norwegian Embassy in the U.S. & Ministry & Andreas Larsson \\
The Finnish Embassy in the U.S. & Ministry & Bjarte Haavik \\
\hline
\end{tabular}




\section{Appendix D: Workshop participants}

\begin{tabular}{|c|c|c|}
\hline Name & Title & Organisation \\
\hline Dorte Salskov-Iversen & Head of Department & Copenhagen Business School, Denmark \\
\hline Kristján Kristjánsson & Executive Director of Qualty & Reykjavik University \\
\hline Marianne Røgeberg & Head of Arctic Affairs & NordForsk \\
\hline Morten Larsen & Chief Consultant & Oxford Research \\
\hline Anders Randrup & Consultant & Oxford Research \\
\hline Andreas Brunsgaard & General Manager & Confederation of Danish Industry, U.S. \\
\hline Monika M Backlund & Senior Advisor & Nordic Council of Ministers \\
\hline Daniel Holmberg & Senior Advisor & Nordic Council of Ministers \\
\hline John Farrell & Executive Director & $\begin{array}{l}\text { USARC - United States Arctic Research } \\
\text { Council }\end{array}$ \\
\hline Mangala Sharma & $\begin{array}{l}\text { Program Director in the Office of International } \\
\text { Science \& Engineering, lead for collaboration } \\
\text { with Nordic Countries }\end{array}$ & NSF - National Science Foundation \\
\hline Jeppe Dørup Olesen & Innovation Attaché & Innovation Center Denmark, Silicon Valley \\
\hline Andras Simonyi & $\begin{array}{l}\text { Managing Director of the centre for transatlantic } \\
\text { relations }\end{array}$ & Johns Hopkins University \\
\hline Debra Cagan & Senior State Department Fellow at CTR & Johns Hopkins University \\
\hline Mariette Hagglund, Fellow & Visiting Fellow/Research Assistant & Johns Hopkins University \\
\hline Bjarte Håvik & $\begin{array}{l}\text { Counselor (Science, Technology and Higher } \\
\text { Education) }\end{array}$ & Royal Norwegian Embassy \\
\hline Trine Eriksen & International Education Officer & Royal Norwegian Embassy \\
\hline Andreas Larsson & Science and Innovation Counselor & Embassy of Sweden, Washington DC \\
\hline Annina Aalto & Cultural Counselor & Embassy of Finland, Washington, D.C. \\
\hline Lars Bo Møller & Deputy Chief of Mission, Ambassador & Royal Danish Embassy, Washington \\
\hline Niels Heltberg & Minister Counselor & Royal Danish Embassy, Washington \\
\hline Ted Zoller & $\begin{array}{l}\text { T.W. Lewis Clinical Professor of Strategy and } \\
\text { Entrepreneurship and Director of the Center for } \\
\text { Entrepreneurial Studies }\end{array}$ & $\begin{array}{l}\text { Kenan-Flagler Business School, Univesity of } \\
\text { North Carolina Chapel Hill }\end{array}$ \\
\hline Robert Strand & Executive Director, Assistant Professor & $\begin{array}{l}\text { Haas School of Business, UC Berkeley, } \\
\text { Copenhagen Business School Centre for } \\
\text { Corporate Social Responsibility }\end{array}$ \\
\hline Brooke Struck & Policy Analyst & Science-Metrix \\
\hline \multicolumn{3}{|c|}{ Participants via Skype connection } \\
\hline Elisabet Idermark & International administrator & Stockholms Universitet \\
\hline Johanna Diehl & International coordinator & Karolinska Instituttet in Sweden \\
\hline Linda Rutledal & Senior Adviser & $\begin{array}{l}\text { SIU - Norwegian Centre for International } \\
\text { Cooperation in Education }\end{array}$ \\
\hline Noel Bynum & International education program coordinator & University of North Carolina Chapel Hill \\
\hline
\end{tabular}


Nordic Council of Ministers

Nordens Hus

Ved Stranden 18

DK-1061 Copenhagen K

www.norden.org

\section{HIGHER EDUCATION, RESEARCH AND INNOVATION}

The vision of the Nordic Council of Ministers for the Nordic region is built on visibility and international engagement. In research and education, the aim is to strengthen international competitiveness and safeguard a leading position in knowledge and welfare. Against this background Oxford Research and the Confederation of Danish Industry has been asked to conduct a feasibility study on how to increase cooperation between the Nordic countries and the U.S. within higher education, research and innovation.

The results of the study shows that cooperation is well established but at the same time there is an interest in and potential for even stronger collaboration. A number of recommendations are given for concrete actions to be taken the by Nordic Council of Ministers and other actors interested in increasing the cooperation between the Nordic countries and the U.S. 